\title{
Improvement of Laccase Activity Via Covalent Immobilization over Mesoporous Silica Coated Magnetic Multiwalled Carbon Nanotubes for the Discoloration of Synthetic Dyes
}

\author{
Pascal Habimana, Jing Gao, Jean Pierre Mwizerwa, Jean Bernard Ndayambaje, Hengrao Liu, \\ Pengqian Luan, Li Ma,* and Yanjun Jiang*
}

Cite This: ACS Omega 2021, 6, 2777-2789

Read Online

ABSTRACT: Due to its environmental friendliness and biodegradable ability, the enzymatic decolorization of azo dyes is the best option. However, the free enzyme suffers from various limitations, including poor stability, no repeatable use, and a high expense, which is the key drawback for its practical use. In this analysis, the laccase enzyme was immobilized in mesoporous silica coated magnetic multiwalled carbon nanotubes $\left.\left(\mathrm{Fe}_{3} \mathrm{O}_{4} \text {-MWCNTs@SiO}\right)_{2}\right)$ by a glutaraldehyde cross-linker to create an easily separable and stable enzyme. Fourier transform infrared (FTIR) spectroscopy, scanning electron microscopy (SEM), and energy-dispersive Xray spectroscopy (EDX) were used to characterize the as-synthesized $\mathrm{Fe}_{3} \mathrm{O}_{4}-\mathrm{MWCNTs} @ \mathrm{SiO}_{2}$. Laccase immobilized in $\mathrm{Fe}_{3} \mathrm{O}_{4}-\mathrm{MWCNTs} @ \mathrm{SiO}_{2}$ showed a good improvement in temperature, $\mathrm{pH}$, and storage stability. Moreover, the operational stability of the biocatalyst was improved, retaining $87 \%$ of its original activity even after 10 cycles of 2,2'-azino-bis(3-ethylbenzothiazoline6-sulfonic acid) (ABTS) oxidation. The biocatalysts were applied for the decolorization of selected azo dyes without a mediator, and up to $99 \%$ of Eriochrome Black T (EBT), $98 \%$ of Acid Red 88 (AR 88), and 66\% of Reactive Black 5 (RB5) were decolorized. Based on these properties, the biocatalysts can be potentially utilized in various environmental and industrial applications.

\section{INTRODUCTION}

Azo dyes have been commonly used for the coloring of various fabrics in the garment industry owing to their robust use and suitability for different substrate materials. ${ }^{1,2}$ It has been also reported that about $70 \%$ of all dyes utilized in industries are azo dyes. ${ }^{1}$ Meanwhile, they are considered as one of the main sources of contaminants in industrial wastewater. ${ }^{2,3}$ In addition, approximately 1 million tons of dyes and pigments are annually manufactured worldwide, and this quantity is continuously expanding every year. ${ }^{4,5}$ Color resulting from dyes is usually the first contaminant to be recognized in wastewater; even $1 \mathrm{mg} / \mathrm{L}$ of dye can be seen with our naked eyes. The effluents discharged from textile or other industries result in serious problems to human beings or aquatic systems. ${ }^{1,6,7}$ Among the azo dyes used, Reactive Black 5 (RB 5), ${ }^{8,9}$ Eriochrome Black T (EBT), ${ }^{10}$ and Acid red 88 (AR $88)^{11}$ are mostly utilized in textile or other industries for coloring materials such as cellulose, cotton fibers, nylon, silk, wool, etc. However, the release of these dyes into the environment causes great problems to human lives since exposure to dyes arouses skin irritations, impaired respiratory system, bladder cancer, acute bronchitis, mutations, etc. ${ }^{12,13}$ Therefore, reports on remediation of harmful dyed effluents before discharge into water bodies are of environmental benefit because of their carcinogenicity, mutagenicity, toxic effects, slow biodegradability, and recalcitrant existence. ${ }^{2,14,15}$
To eliminate dyes from wastewater, various methods including chemical oxidation, membrane filtration, adsorption, and photocatalytic degradation have been analyzed in detail. $^{2,15}$ However, it has been reported that these methods require a high cost and are complex to operate, and they also can mostly generate secondary contaminants. ${ }^{2,16}$ Hence, safe and environmentally benign approaches such as the use of enzymes or microorganisms are crucial for the treatment of wastewater containing dyed effluents. ${ }^{17,18}$ Enzymes, as the green biocatalysts, could be employed in the removal of dyes from wastewater. However, free enzyme suffers from different limitations including product contamination, low stability, nonreusability, and high production costs. Enzyme immobilization, in which the free enzyme is attached on the solid support, can avoid these limitations by preserving the protein structure of the enzyme, thus minimizing the product contamination. ${ }^{19,20}$ Therefore, owing to its advantages including easy recovery, low energy, low cost, operational

Received: October 18, 2020

Accepted: January 13, 2021

Published: January 22, 2021 
stability, ability to be reused several times, etc., the immobilized enzyme is more preferable than its free form. ${ }^{20}$ The immobilization of an enzyme can be carried out by employing diverse methods including chemical and physical methods that affect the enzyme properties and thus its utilization in particular processes. ${ }^{18-20}$ The problems associated with enzyme immobilization are to identify new support materials with suitable structure and properties of enzymes, and an immobilization method. Covalent bonding is the best method for immobilizing enzymes because it maintains its tertiary structure, strongly binds to the support material, and prevents enzyme leaching from the support. ${ }^{19-21}$

Recently, different materials including nanotubes, nanoparticles, nanofibers, and activated carbon have been utilized as supports for enzyme immobilization. ${ }^{21}$ Among them, carbon nanotubes are the most popular support for enzyme immobilization owing to their unique characteristics including the layered and hollow structures, low price, high chemical and thermal stabilities, high mechanical strength, high enzyme loading, good biocompatibility, and large surface area to volume ratio. ${ }^{21,22}$ However, their practical utilization in bioremediation is restricted by their agglomeration capacity as a result of the strong attraction between the small carbon particles, which leads to the smaller surface area. ${ }^{22}$ To remove this limitation, carbon nanotubes can be prepared in advance by a surface modification to decrease the agglomeration and increase the accessible surface area. ${ }^{22-24}$ Therefore, mesoporous silica materials modified carbon nanotubes may be advantageous owing to their quicker mass transfer, enhanced interfacial bonding ability, hydrophilicity property, mechanical stability, and high enzyme loading, and different functional groups can be attached on it, which preclude enzyme leaching. ${ }^{25-27}$

Nonetheless, a major challenge is its separation from reaction mixtures and the low adsorption capacity. The magnetic functionalization is the best way for its fast, suitable, and efficient removal from reaction mixtures. ${ }^{28,29}$ Therefore, inspired by the reported works, mesoporous silica coated magnetic multiwalled carbon nanotubes were developed and used in the enzyme immobilization process. ${ }^{30}$ Laccase enzyme was selected as a model enzyme due to its wide range of substrates, ability to oxidize organic and some inorganic substrates, and ability to remove xenobiotics from industrial effluents as well as discoloration of dyes. In addition, compared to the peroxidase enzyme, the laccase enzyme does not need hydrogen peroxide $\left(\mathrm{H}_{2} \mathrm{O}_{2}\right)$ but can oxidize organic compounds with oxygen $\left(\mathrm{O}_{2}\right)$ as a co-substrate..$^{20,31-33}$

Several studies have employed immobilized laccase for the removal of dyes from industrial wastewater; for instance, Larissa et al. ${ }^{34}$ reported the decolorization of Acid Red 88 by immobilized laccase with thiosulfinate-agarose as a carrier. They observed that $97 \%$ color removal needed $24 \mathrm{~h}$. Katarzyna et al. ${ }^{35}$ utilized immobilized laccase with $\mathrm{TiO}_{2}-\mathrm{ZrO}_{2}-\mathrm{SiO}_{2}$ as a carrier to decolorize Reactive Black 5 . The result showed that the color removal efficiency of the dye in $24 \mathrm{~h}$ was $77 \%$. In another report, ${ }^{20}$ they investigated the decolorization of Reactive Black 5, Reactive Red 2, Acid Orange 7, and Acid Blue 74 using immobilized laccase with mesoporous carbon from pecan shells as a carrier. The results illustrated that the color removal efficiencies of the dyes in $72 \mathrm{~h}$ were $5,48,94$, and $92 \%$, respectively. However, the decolorization time was too long and most of them used mediators, which increase the cost during the multiple reuses.
It has been also reported that the decolorization of azo dyes by laccase enzyme depends considerably on the structures of dyes. ${ }^{3,34}$ Therefore, in this present study, we have characterized mesoporous silica coated magnetic multiwalled carbon nanotubes $\left(\mathrm{Fe}_{3} \mathrm{O}_{4}\right.$-MWCNTs@SiO ${ }_{2}$ ) covalently immobilized with laccase for the decolorization of azo dyes from wastewater without a mediator to solve this problem. Moreover, different factors including glutaraldehyde concentrations, cross-linking time, immobilization time, enzyme concentration, as well as temperature, $\mathrm{pH}$, reusability, and storage stability, which can affect enzyme activity, were also optimized. Based on obtained results, the enzyme immobilized in mesoporous silica coated magnetic multiwalled carbon nanotubes $\left(\mathrm{Fe}_{3} \mathrm{O}_{4}\right.$-MWCNTs@ $\mathrm{SiO}_{2}$ ) is a novel efficient method for effectively treating wastewater containing dyes or other harmful organic materials.

\section{RESULTS AND DISCUSSION}

Characterization of MWCNT, $\mathrm{Fe}_{3} \mathrm{O}_{4}-\mathrm{MWCNT}, \mathrm{Fe}_{3} \mathrm{O}_{4^{-}}$ MWCNT@SiO ${ }_{2}$, and Immobilized Laccase. Scanning electron microscopy (SEM) images were collected and used to observe the structural morphology of the as-prepared samples. As shown in Figure S1a, the outer part of pristine multiwalled carbon nanotubes (MWCNT) is a thin long tubular structure without any other particles on the wall. However, after coating with $\mathrm{Fe}_{3} \mathrm{O}_{4}$, there are a lot of nanoparticles connected on the outer part of MWCNTs, indicating that $\mathrm{Fe}_{3} \mathrm{O}_{4}$ was attached on the surface of MWCNTs (Figure S1b). In addition, to confirm the structural composition of the synthesized $\mathrm{Fe}_{3} \mathrm{O}_{4}$-MWCNTs, energydispersive X-ray spectroscopy (EDX) spectra were collected during scanning electron microscopy (SEM) imaging (Figure $\mathrm{S} 2 \mathrm{a}$ ). The obtained results show the appearance of $\mathrm{O}$ and $\mathrm{Fe}$ elements, further confirming the existence of $\mathrm{Fe}_{3} \mathrm{O}_{4}$ in the structural composition, which is in good agreement with the reported work. ${ }^{36}$ Moreover, to increase the surface area and make the as-synthesized magnetic multiwalled carbon nanotubes $\left(\mathrm{Fe}_{3} \mathrm{O}_{4}\right.$-MWCNTs $)$ more hydrophilic, as well as facilitate the functionalization process, $\mathrm{SiO}_{2}$ was coated on the surface of $\mathrm{Fe}_{3} \mathrm{O}_{4}$-MWCNTs with the aid of cetyltrimethyl ammonium bromide (CTAB) as a surfactant, and the silica source was tetraethylorthosilicate (TEOS). Finally, CTAB was extracted using an ion-exchange method. The structure was changed due to the mesoporous silica shell on $\mathrm{Fe}_{3} \mathrm{O}_{4}$-MWCNTs as shown in Figure S1c. To get more information about the structure of the as-synthesized composites, the energy-dispersive $\mathrm{X}$-ray spectroscopy (EDX) study of the $\mathrm{Fe}_{3} \mathrm{O}_{4}-\mathrm{MWCNT} @ \mathrm{SiO}_{2}$ was displayed in Figure $\mathrm{S} 2 \mathrm{~b}$. $\mathrm{Fe}, \mathrm{Si}$, and $\mathrm{O}$ elements can be observed, confirming that the $\mathrm{Fe}_{3} \mathrm{O}_{4}$-MWCNT@SiO 2 nanocomposites were successfully synthesized. ${ }^{36}$

As indicated in Figure S1d, there was a stable suspension of $\mathrm{Fe}_{3} \mathrm{O}_{4}$-MWCNT@SiO $\mathrm{S}_{2}$ in an aqueous medium (water), which proves that no agglomeration of the as-synthesized microparticles occurred, and a magnetic field was applied to test the separation capacity, which was done in $10 \mathrm{~s}$.

To investigate the functional groups that exist in our samples, a Fourier transform infrared (FTIR) analysis of $\mathrm{Fe}_{3} \mathrm{O}_{4}$-MWCNT@CTAB@SiO 2 and $\mathrm{Fe}_{3} \mathrm{O}_{4}$-MWCNT@SiO after the extraction of $\mathrm{CTAB}$ was performed. As can be seen from Figure 1, the broad peaks around 2855 and $2926 \mathrm{~cm}^{-1}$ are attributed to the $-\mathrm{CH}_{2}$ group from $\mathrm{CTAB}$, proving that $\mathrm{CTAB}$ was successfully enclosed into $\mathrm{Fe}_{3} \mathrm{O}_{4}-\mathrm{MWCNT} @ \mathrm{SiO}_{2}$. After the extraction of $\mathrm{CTAB}$, the intensity of absorption peaks around 2855 and $2926 \mathrm{~cm}^{-1}$ decreased obviously and become 


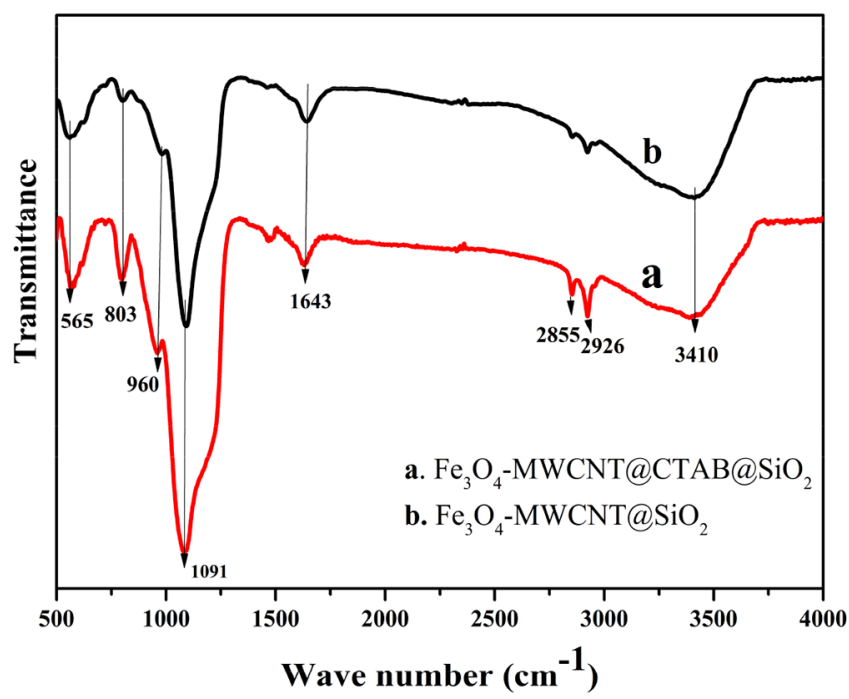

Figure 1. FTIR spectra of (a) $\mathrm{Fe}_{3} \mathrm{O}_{4}-\mathrm{MWCNT} @ \mathrm{CTAB} @ \mathrm{SiO}_{2}$ and (b) $\mathrm{Fe}_{3} \mathrm{O}_{4}-\mathrm{MWCNT} @ \mathrm{SiO}_{2}$.

weaker, confirming that most of $\mathrm{CTAB}$ was removed. The strong band peaks around $1091 \mathrm{~cm}^{-1}$ in curves (a) and (b) are assigned to the stretching vibration of $\mathrm{Si}-\mathrm{O}-\mathrm{Si}$, illustrating that the $\mathrm{SiO}_{2}$ shell was successfully enclosed on $\mathrm{Fe}_{3} \mathrm{O}_{4^{-}}$ MWCNTs. The intensity of absorption peaks around $960 \mathrm{~cm}$ and $803 \mathrm{~cm}^{-1}$ is consistent with the $\mathrm{Si}-\mathrm{OH}$ and $\mathrm{Si}-\mathrm{O}$ stretching frequencies, respectively. The peak around 3410 $\mathrm{cm}^{-1}$ is attributed to the $-\mathrm{OH}$ groups in curves (a) and (b), respectively. Furthermore, a broad peak that is attributed to the stretching vibration of $\mathrm{Fe}-\mathrm{O}-\mathrm{Fe}$ in $\mathrm{Fe}_{3} \mathrm{O}_{4}$ was observed at around $565 \mathrm{~cm}^{-1}$ (Figure 1a,b), indicating that $\mathrm{Fe}_{3} \mathrm{O}_{4}$ has been successfully coated on MWCNTs. Moreover, the peak around $1643 \mathrm{~cm}^{-1}$ is assigned to the $\mathrm{C}=\mathrm{O}$ stretching frequencies from the acid treatment of MWCNTs. The results are in agreement with the reported methods. ${ }^{36,37}$

The porosity of mesoporous silica coated magnetic multiwalled carbon nanotubes $\left(\mathrm{Fe}_{3} \mathrm{O}_{4}-\mathrm{MWCNT} @ \mathrm{SiO}_{2}\right)$ was examined by nitrogen adsorption/desorption isotherms and showed a typical type IV isotherm with a mesoporous structure (Figure 2a). The corresponding mesopore size was $11.47 \mathrm{~nm}$
(Figure $2 \mathrm{~b}$ ), and the Brunauer-Emmett-Teller (BET) surface area of $\mathrm{Fe}_{3} \mathrm{O}_{4}$-MWCNT@SiO $\mathrm{M}_{2}$ was $428.1 \mathrm{~m}^{2} / \mathrm{g}$. The high surface area is assigned to the porous silica shell and nanotube structure, which could facilitate the attachment of enzymes. ${ }^{36-38}$

Characterization of Laccase@ $\mathrm{Fe}_{3} \mathrm{O}_{4}-\mathrm{MWCNT} @ \mathrm{SiO}_{2}$. Mesoporous silica coated magnetic multiwalled carbon nanotubes $\left(\mathrm{Fe}_{3} \mathrm{O}_{4}\right.$-MWCNTs@SiO $\left.\mathrm{O}_{2}\right)$ are an efficient support for immobilizing enzymes, evidently enhancing the enzyme catalytic activity, reusability, and easy separation from the aqueous solution using a magnetic field. In this study, laccase was selected as a model enzyme and employed in the decolorization of three types of dyes because diverse chemical structures of dyes can be decolorized differently. ${ }^{3,20}$ Before immobilizing the enzyme, glutaraldehyde was utilized as a cross-linker to activate the support. Glutaraldehyde improves the reusability and stability of the enzyme and prevents enzyme leaching during the reaction process, as a result of the strong interaction between the substrate and enzyme molecule; moreover, glutaraldehyde is versatile and an inexpensive reagent. This cross-linker has two aldehyde functional groups; one is capable of covalently reacting with the support, while the other reacts with the amino groups of enzymes, leading to the immobilization of enzymes. ${ }^{22,39,40}$

To further investigate the influence of glutaraldehyde concentrations on the immobilization of laccase, diverse glutaraldehyde concentrations were tested. As indicated in Figure S3a, the activity of the biocatalytic system (laccase@ $\mathrm{Fe}_{3} \mathrm{O}_{4}$-MWCNT@SiO 2 ) was augmented with the rising initial glutaraldehyde concentrations from 1 to $1.5 \mathrm{wt} \%$, and the optimum relative activity was obtained with the use of a $1.5 \mathrm{wt}$ $\%$ glutaraldehyde concentration. Further increasing the initial glutaraldehyde concentrations caused laccase activity to decline sharply. This could be explained as follows: when glutaraldehyde concentration is too low, the aldehyde groups in $\mathrm{Fe}_{3} \mathrm{O}_{4^{-}}$ MWCNT@SiO ${ }_{2}$ are restricted, leading to a lower activity of the immobilized enzyme and also a decrease in laccase loading. ${ }^{39,40}$

When the glutaraldehyde concentration is too high, more aldehyde groups will be formed in mesoporous silica coated magnetic multiwalled carbon nanotubes $\left(\mathrm{Fe}_{3} \mathrm{O}_{4}\right.$-MWCNT@ $\mathrm{SiO}_{2}$ ), and then too much aldehyde groups could conjugate
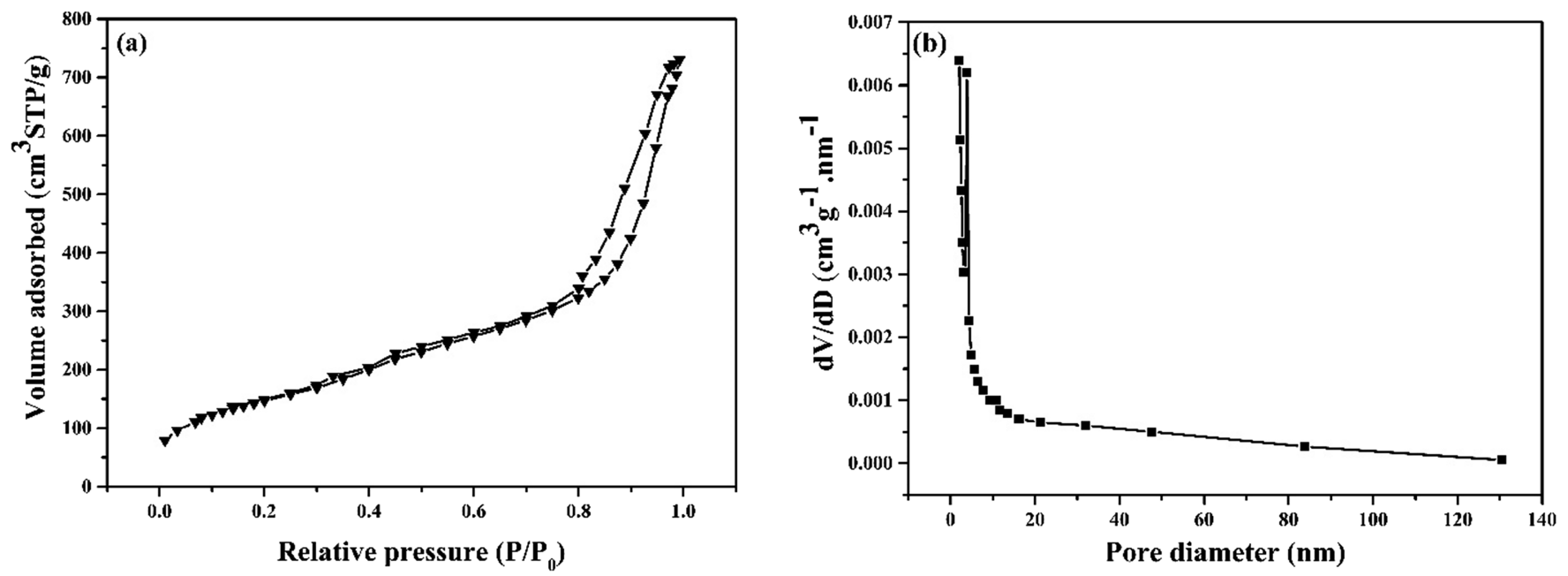

Figure 2. Nitrogen adsorption-desorption isotherm (a) and pore size distribution profile (b) of mesoporous silica coated magnetic multiwalled carbon nanotubes. 

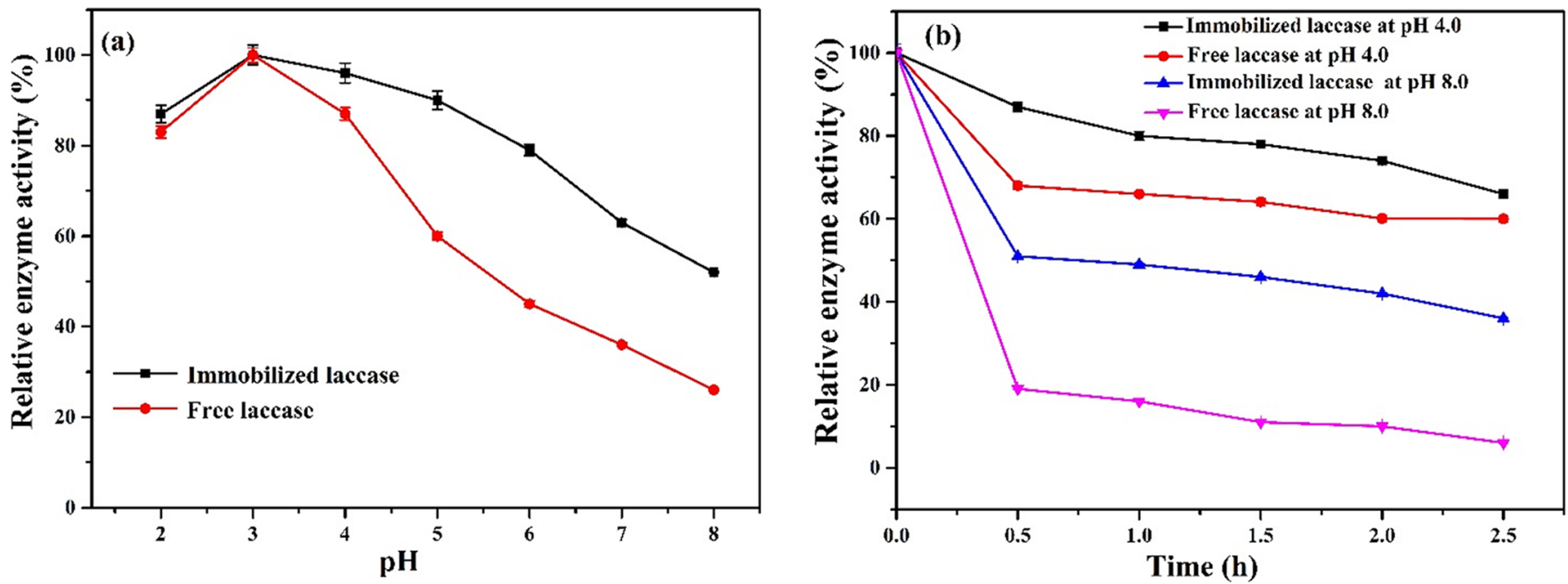

Figure 3. (a) Effect of reaction $\mathrm{pH}$ values and (b) $\mathrm{pH}$ stability under $\mathrm{pH} 4.0$ and 8.0 on the activity of free and immobilized laccase.

with the $-\mathrm{NH}_{2}$ groups of laccase; thus, the laccase enzyme was more and more densely immobilized in $\mathrm{Fe}_{3} \mathrm{O}_{4}$-MWCNT@ $\mathrm{SiO}_{2}$. Then, the activity of laccase immobilized in $\mathrm{Fe}_{3} \mathrm{O}_{4}$ MWCNT@SiO 2 was augmented. However, when glutaraldehyde concentrations were further increased, there were more reacting sites between the enzyme molecules and activated $\mathrm{Fe}_{3} \mathrm{O}_{4}-\mathrm{MWCNT} @ \mathrm{SiO}_{2}$. More laccase enzymes were bound smoothly in $\mathrm{Fe}_{3} \mathrm{O}_{4}$-MWCNT@SiO${ }_{2}$ by the formation of Schiff's bases and then lost its flexibility for the reaction performance. $^{21,39}$ Additionally, a very high glutaraldehyde concentration could destruct the enzyme's structure or result in an unrestricted polymerization. ${ }^{39}$ Thus, the relative activity of laccase was decreased.

Therefore, the optimum glutaraldehyde concentration was 1.5 wt \%, which was then used in this study.

Similar observations were reported by Rouhani et al., ${ }^{40}$ where they found an increase in the laccase activity by varying concentration of glutaraldehyde from 2 to 5\%. The optimal glutaraldehyde concentration for the best activity performance was found to be $5 \%$ giving $86 \%$ recovery activity. Beyond the optimal concentration (i.e., from 5 to $8 \%$ ), the recovery activity was declined sharply. Dajun et al. ${ }^{41}$ reported similar observations using glutaraldehyde concentrations ranging from 1 to $6 \%$, with an optimal glutaraldehyde concentration of $5 \%$. Kadam et al. $^{42}$ reported similar results with a recovery activity of $95.13 \%$ and laccase loading of $100.12 \mathrm{mg} \mathrm{g}^{-1}$ using an optimal glutaraldehyde concentration of $2.5 \%$. Kashefi et al. ${ }^{43}$ reported similar observations with a $156.5 \mathrm{mg} \mathrm{g}^{-1}$ laccase loading and $64.6 \%$ immobilization yield using an optimal glutaraldehyde concentration of $3 \%(\mathrm{v} / \mathrm{v})$ and $0.9 \mathrm{mg} / \mathrm{mL}$ of initial laccase concentration.

Liya et al. ${ }^{39}$ also reported similar observations when the optima glutaraldehyde concentrations were $0.8,1.2$, and $1.6 \%$ with 66,5431 , and $63,436 \mathrm{U} / \mathrm{g}_{\text {support }}$ activities for immobilized nitrile hydratase (NHase), lipase B from Candida antarctica (CALB), and penicillin G acylase (PGA), respectively.

During the immobilization process, the cross-linking time is also a key factor that can significantly affect the activity of the enzyme. $^{41}$ As seen in Figure S3b, with an increase of crosslinking time, the immobilized enzyme activity is also increased. The highest activity after immobilizing laccase was obtained after cross-linking for $2 \mathrm{~h}$, showing that this reaction time is favorable for the enzyme to be covalently attached in $\mathrm{Fe}_{3} \mathrm{O}_{4^{-}}$
MWCNT@SiO . However, on further increasing the crosslinking time, the activity of laccase immobilized in $\mathrm{Fe}_{3} \mathrm{O}_{4}$ MWCNT@SiO ${ }_{2}$ seemed to decline. The decrease and increase of enzyme activity after cross-linking could be explained as follows: (1) when the cross-linking time is too short, the aldehyde groups from glutaraldehyde molecules could not react completely with the support, resulting in a low amount of enzyme attached on the support surface, and (2) when the cross-linking time is too long, more and more aldehyde groups could be grafted in the support, leading to the alteration of the tertiary structure of the enzyme and limited conditions for more enzyme to be covalently attached in the support materials. ${ }^{39-42,44}$ Similar observations have been reported. $^{40-42}$ Based on the obtained results, the optimal cross-linking time was $2 \mathrm{~h}$ and was adopted in further experiments.

The influence of the initial concentration of enzyme on the activity of enzyme immobilized in $\mathrm{Fe}_{3} \mathrm{O}_{4}-\mathrm{MWCNT} @ \mathrm{SiO}_{2}$ was investigated. As shown in Figure S3c, when the concentration of laccase increased from 2 to $12 \mathrm{mg} / \mathrm{mL}$, the relative activities of laccase immobilized in $\mathrm{Fe}_{3} \mathrm{O}_{4}$-MWCNT@SiO 2 were increased. The maximum relative activity of laccase immobilized in $\mathrm{Fe}_{3} \mathrm{O}_{4}$-MWCNT@SiO 2 was obtained when the concentration of laccase was $12 \mathrm{mg} / \mathrm{mL}$. Furthermore, when the laccase concentration was increased from 12 to $14 \mathrm{mg} / \mathrm{mL}$, the immobilized laccase activity started to decline slightly, showing that there were no adequate aldehyde groups in $\mathrm{Fe}_{3} \mathrm{O}_{4}$-MWCNT@SiO $\mathrm{M}_{2}$ that could further covalently be conjugated with the amino groups of the laccase enzyme. This could be explained by the following factors: First, when the enzyme concentration is relatively low, the enzyme might not successfully bind with the $\mathrm{Fe}_{3} \mathrm{O}_{4}-\mathrm{MWCNT} @ \mathrm{SiO}_{2}$, resulting in a low enzyme activity. Second, when the enzyme concentration is too high, the support gets more crowded, causing a steric hindrance that decreases the enzyme activity, and is easily affected by the surrounding microenvironment. Similar observations have been reported. ${ }^{39-41}$ Based on the obtained results, the initial concentration of laccase selected for further experiments was $12 \mathrm{mg} / \mathrm{mL}$.

During the immobilization process, the immobilization time is also a key factor that can significantly affect the activity of the enzyme. As illustrated in Figure S3d, the activity of laccase immobilized in $\mathrm{Fe}_{3} \mathrm{O}_{4}$-MWCNT@SiO 2 was increased with an 

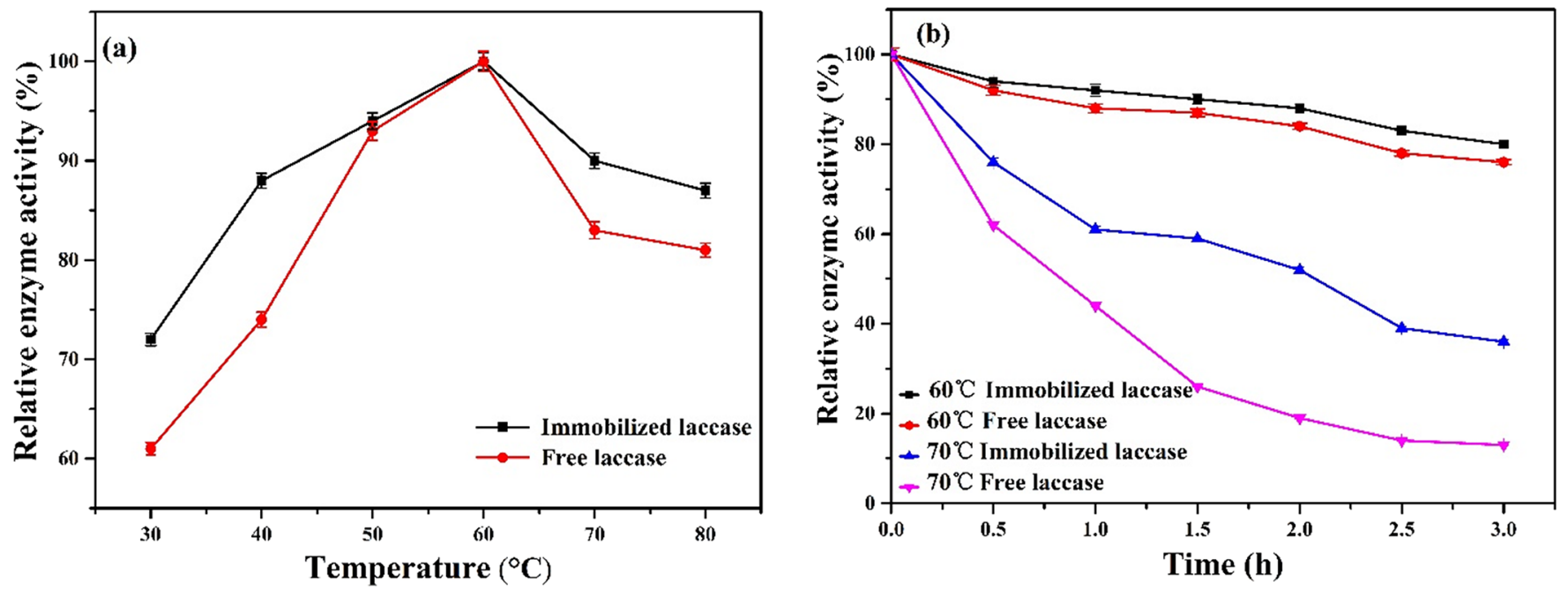

Figure 4. (a) Effect of temperature $\left(30-80{ }^{\circ} \mathrm{C}\right)$ and (b) thermal stability at 60 and $70{ }^{\circ} \mathrm{C}$ on the activity of free and immobilized laccase.

increase of immobilization time up to some extent. The maximum activity of laccase immobilized in $\mathrm{Fe}_{3} \mathrm{O}_{4}$ MWCNT@SiO 2 was achieved when the immobilization time was $2 \mathrm{~h}$; however, with a further increase in immobilization time up to $3 \mathrm{~h}$, the activity of immobilized laccase diminished sharply. This can be explained as follows: When the immobilization time is too short, laccase enzymes almost do not have adequate time to enter into the porous $\mathrm{Fe}_{3} \mathrm{O}_{4^{-}}$ MWCNT@SiO ${ }_{2}$, resulting in the low activity of the immobilized enzyme. When the immobilization time is adequate, the enzyme molecules covalently conjugate with $\mathrm{Fe}_{3} \mathrm{O}_{4}-\mathrm{MWCNT} @ \mathrm{SiO}_{2}$ at the saturation state, resulting in the maximum immobilized laccase activity. However, when the immobilization time is too long, laccase is more and more overloaded into the $\mathrm{Fe}_{3} \mathrm{O}_{4}-\mathrm{MWCNT} @ \mathrm{SiO}_{2}$, leading to a decrease in enzyme activity. Moreover, if the immobilization time continues to increase, too many enzyme molecules in the $\mathrm{Fe}_{3} \mathrm{O}_{4}$-MWCNT@SiO 2 could be easily influenced by the external microenvironment (such as temperature, $\mathrm{pH}$, etc.), which is another factor for the reduction of enzyme activity. Similar observations have been reported. ${ }^{39-43}$

Biochemical Characterization of the Immobilized and Free Laccase. Influence of $\mathrm{pH}$ Values and $\mathrm{pH}$ Stability on Laccase Activity. The $\mathrm{pH}$ is a key factor to consider because it can influence the activity of enzymes due to the ionization change of enzyme functional groups. ${ }^{15}$ It has been also reported that the optimal $\mathrm{pH}$ for laccases is considerably dependent on the type of substrate used as well as its redox potential. ${ }^{45}$ Moreover, the stability of fungal laccase depends on the acidic medium, and the $\mathrm{pH}$ stability differs substantially depending on the origin of the enzyme. ${ }^{20,45,46}$ In this work, the effect of $\mathrm{pH}$ on the activity of laccase was tested over a wide range of $\mathrm{pH}$ values $(2-8)$. As can be seen in Figure $3 \mathrm{a}$, the maximal relative activity was obtained at $\mathrm{pH} 3.0$ for both the free and immobilized enzymes. However, lower activity levels of the free enzyme relative to the immobilized form were found in all situations, which suggest that the immobilized enzyme is extremely stable at all $\mathrm{pH}$ values. Although immobilized laccase sustained 90 and $79 \%$ relative activity at $\mathrm{pH} 5.0$ and 6.0, the free form preserved 52 and $45 \%$ relative activity under the same conditions. The optimal activity for both free and immobilized laccase at $\mathrm{pH} 3$ has also been reported. ${ }^{3,46}$ On the other hand, the activity of laccase@ $@ \mathrm{Fe}_{3} \mathrm{O}_{4}-\mathrm{MWCNT} @ \mathrm{SiO}_{2}$ on both acidic and alkaline media remained slightly higher than that of the free form, which may be attributed to its stability and the strong interaction between the enzyme and support materials. ${ }^{15,46}$ However, the relative activity for both immobilized and free laccase in alkaline media was decreased but only slightly for the immobilized laccase. This has been ascribed to the hydroxyl anion inhibition to type 2 /type 3 copper on laccase centers at higher $\mathrm{pH}$, which prevents the binding of oxygen, leading to a lower activity. ${ }^{3,45,46}$ Therefore, the activity of free laccase declines along with the increasing $\mathrm{pH}$, and about $26 \%$ of the relative activity is retained at an alkaline medium with $\mathrm{pH} 8.0$ for free enzyme, whereas the immobilized enzyme retains $52 \%$. The higher activity profile for wide $\mathrm{pH}$ values for the immobilized enzyme has also been reported. ${ }^{3,20,44,47}$ Based on these results, the immobilized laccase is more adaptable to acidic and alkaline media, which is beneficial for a wide application.

The external microenvironment could significantly affect the enzyme activity, particularly extreme conditions that may destruct enzyme structures. ${ }^{3,15}$ In the present work, the stability of the immobilized and free laccase under $\mathrm{pH}$ was tested. Laccase was incubated into diverse $\mathrm{pHs}, \mathrm{pH} 4.0$ and 8.0, for $2.5 \mathrm{~h}$, and the activity was then examined. As shown in Figure $3 \mathrm{~b}$, under an acidic condition $(\mathrm{pH} 4.0)$, the free laccase maintained $60 \%$ of its initial activity when incubated at $25{ }^{\circ} \mathrm{C}$ for $2.5 \mathrm{~h}$, while the laccase immobilized in $\mathrm{Fe}_{3} \mathrm{O}_{4}$-MWCNT@ $\mathrm{SiO}_{2}$ retained $66 \%$ of its original activity under the same conditions. Under an alkaline condition $(\mathrm{pH} 8.0)$, the free laccase maintained $6 \%$ of its initial activity when incubated at $25{ }^{\circ} \mathrm{C}$ for $2.5 \mathrm{~h}$, while the laccase immobilized in $\mathrm{Fe}_{3} \mathrm{O}_{4}$ MWCNT@SiO ${ }_{2}$ retained 36\% of its initial activity under the same conditions. The higher activity for the immobilized enzyme compared to the free form could be attributed to the strong interaction between the glutaraldehyde-activated $\mathrm{Fe}_{3} \mathrm{O}_{4}$ MWCNT@SiO ${ }_{2}$ and enzyme molecules, which reduces the surrounding microenvironment interfaces. ${ }^{15,43,44}$

The relative activity sharply declined for both enzymes but only slightly for the laccase immobilized in $\mathrm{Fe}_{3} \mathrm{O}_{4}$-MWCNT@ $\mathrm{SiO}_{2}$ contrasted to the free form. This could be attributed to the increased quantity of hydroxyl ions in the surrounding medium, which limits oxygen to bind to type 2 or type 3 of laccase copper centers. ${ }^{3,48}$ Based on these results, the laccase immobilized in $\mathrm{Fe}_{3} \mathrm{O}_{4}$-MWCNT@SiO 2 was more stable than 

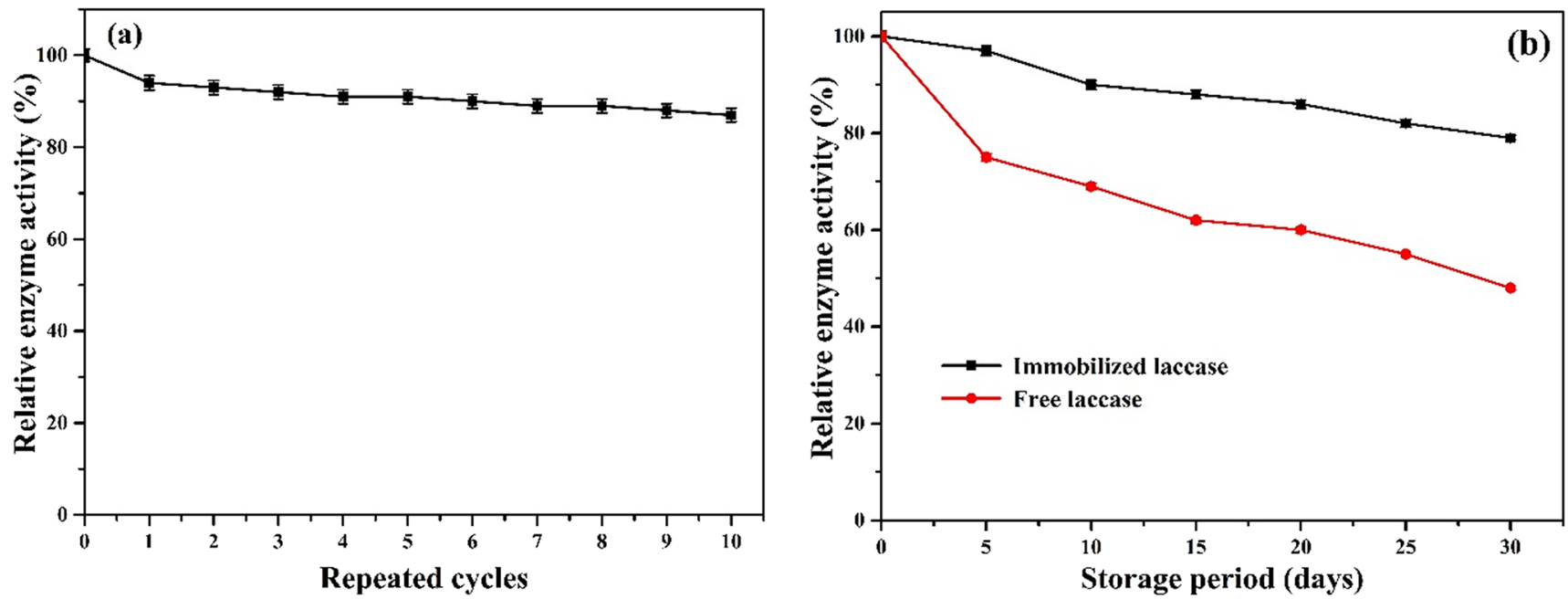

Figure 5. (a) Reusability of immobilized laccase in the batch oxidation of ABTS at $60{ }^{\circ} \mathrm{C}$ and (b) comparison of storage stability of free and immobilized laccase under $\mathrm{pH} 3.0$ at $4{ }^{\circ} \mathrm{C}$ for 30 days.

the free laccase for all cases, which is attributed to the formation of the strong covalent bond and more accessibility of laccase active sites, and also, the as-synthesized $\mathrm{Fe}_{3} \mathrm{O}_{4}$ MWCNT@SiO 2 protect the enzyme from the surrounding microenvironment, resulting in a reduced structural conformational change. ${ }^{3,44,49}$

Influence of Temperature and Thermal Stability on Laccase Activity. During the enzyme immobilization process, the temperature is a key factor to control because it can significantly influence the activity of the enzyme. ${ }^{3,15}$ In this work, the influence of temperature on the activity of the immobilized and free laccase was investigated. As illustrated in Figure $4 \mathrm{a}$, with an increase in the temperature, the activity of both enzymes increase within the temperature ranging from 30 to $60{ }^{\circ} \mathrm{C}$, with a slightly higher activity for the immobilized enzyme compared to the free form, but with a further increase in temperature from 60 to $80{ }^{\circ} \mathrm{C}$, the activity of both enzymes decreased but only slightly for the immobilized laccase. The optimal temperature for both the immobilized and free enzymes was $60{ }^{\circ} \mathrm{C}$. Moreover, the laccase immobilized in $\mathrm{Fe}_{3} \mathrm{O}_{4}$-MWCNT@SiO 2 is more stable at a high temperature contrasted to the free form. At $80{ }^{\circ} \mathrm{C}$, the free enzyme maintained $81 \%$ of its relative activity, while the immobilized enzyme retained $87 \%$ of its relative activity under the same condition (10 min for each reaction). This is in agreement with the reported works, ${ }^{3,49}$ which could be explained as follows: Although an increase in temperature is advantageous to the strong conjugation of the laccase to the support, it could stimulate the molecular shifting of the enzyme to high activity. ${ }^{48,-39}$ However, a further increase in temperature may lead to the loss of enzyme activity due to the denaturation of the enzyme structure. $3,44,50$

Thermal stability is the most significant factor for industrial applications of the biocatalyst. ${ }^{3,15}$ In this work, we have evaluated the thermal stability of the free enzyme compared to the immobilized enzyme. This comparison was carried out by incubating the immobilized and free laccase in a buffer $(\mathrm{pH}$ 3.0) at temperatures of 60 and $70{ }^{\circ} \mathrm{C}$ for $3 \mathrm{~h}$. After incubation, laccase activities were tested at $25^{\circ} \mathrm{C}$. As can be seen in Figure $4 \mathrm{~b}$, the free enzyme retains $76 \%$ of its initial activity when incubated at $60{ }^{\circ} \mathrm{C}$ for $3 \mathrm{~h}$, while the immobilized enzyme retains $80 \%$ of its original activity under the same conditions.
When the temperature was increased up to $70{ }^{\circ} \mathrm{C}$, the free enzyme loses up to $13 \%$ of its activity for $3 \mathrm{~h}$, whereas the immobilized enzyme retains $36 \%$ of its relative activity under the same conditions. The lower activity of the free enzyme at a higher temperature has also been reported.,40-43 The enhanced thermal stability of laccase after immobilization in activated $\mathrm{Fe}_{3} \mathrm{O}_{4}$-MWCNT@SiO 2 might be caused by the following reasons: The structural stability of laccase covalently attached on $\mathrm{Fe}_{3} \mathrm{O}_{4}$-MWCNT@SiO 2 by glutaraldehyde molecules could generate a strong enzyme-support reaction, which makes the enzyme stable at elevated temperatures, and the covalent interactions between the activated support and enzyme molecules also protected the molecular motions of enzyme, which may lead to the improved rigidity of the protein structure of the enzyme and limited its denaturation at high temperatures. ${ }^{3,39,44}$ Furthermore, the structural pores of $\mathrm{Fe}_{3} \mathrm{O}_{4}$ MWCNT@SiO ${ }_{2}$ can protect the enzyme from the surrounding environment, and the free laccase was denatured at a high temperature because no additional covalent bond and also can be easily influenced by the surrounding microenvironment. ${ }^{3,45,46}$ In addition, the laccase immobilized on individual multiwalled carbon nanotubes did not improve its thermal stability and showed a poorer stability than the free enzyme. ${ }^{46,51}$ Based on these results, an improvement in the thermal stability of the immobilized enzyme in $\mathrm{Fe}_{3} \mathrm{O}_{4}$ MWCNT@SiO ${ }_{2}$ could be beneficial for its industrial practical utilization.

Reusability Assessment of the Biocatalyst. The reusability of the enzyme is one of the principal expediencies of immobilizing enzymes. This characteristic of reutilizing enzymes in multiple cycles is the most significant factor for environmental and industrial applications based on its cost effectiveness. ${ }^{15}$ Thus, the reusability of laccase@ $@ \mathrm{Fe}_{3} \mathrm{O}_{4}$ MWCNT@SiO ${ }_{2}$ was also investigated. The obtained results showed that the laccase@ $\mathrm{Fe}_{3} \mathrm{O}_{4}-\mathrm{MWCNT} @ \mathrm{SiO}_{2}$ could be reutilized up to 10 times with $87 \%$ remaining activity (Figure $5 a)$, and the reduction of activity after several cycles could be a result of the loss of enzyme structure or slight denaturation of enzyme and product inhibition. ${ }^{3,44}$ Similar trend results were reported where the immobilized laccase retained $50 \%$ after 10 cycles of oxidizing 2,2'-azino-bis(3-ethylbenzothiazoline-6sulfonic acid) (ABTS), ${ }^{52}$ and the laccase immobilized on 
Sepharose-linked antibody retained $44 \%{ }^{3}$ which is lower than that of the laccase immobilized in $\mathrm{Fe}_{3} \mathrm{O}_{4}-\mathrm{MWCNT} @ \mathrm{SiO}_{2}$. The improved reusability of this synthesized biocatalyst showed that the $\mathrm{Fe}_{3} \mathrm{O}_{4}-\mathrm{MWCNT} @ \mathrm{SiO}_{2}$ aid in retaining the activity of the enzyme and would prevent the enzyme from denaturation due to the strong interaction between the enzyme and $\mathrm{Fe}_{3} \mathrm{O}_{4^{-}}$ MWCNT@SiO 2 support material, which prevents enzyme leaching from the support; thus, the immobilized laccase in $\mathrm{Fe}_{3} \mathrm{O}_{4}$-MWCNT@SiO 2 could be utilized several times.

Storage Stability of the Immobilized and Free Laccase. Enzyme storage is a potential key factor to consider because enzymes can be influenced by the external microenvironment and may be deactivated when stored under certain conditions. ${ }^{3,15}$ Enzymes can be protected from the surrounding environment by using immobilization technology and can maintain the activity to some degree. Therefore, the storage stability of the enzyme was investigated by keeping both enzymes at $4{ }^{\circ} \mathrm{C}$ in a buffer ( $\mathrm{pH} 3.0$ ) for 30 days (Figure $5 \mathrm{~b}$ ). The results obtained showed that laccase@ $\mathrm{Fe}_{3} \mathrm{O}_{4}-\mathrm{MWCNT} @$ $\mathrm{SiO}_{2}$ can keep $79 \%$ of relative activity up to the 30 th day, while the free laccase retained $48 \%$ of relative activity under the same condition. Based on these results, the synthesized $\mathrm{Fe}_{3} \mathrm{O}_{4}$ MWCNT@SiO $\mathrm{S}_{2}$ could protect the enzymes from the external microenvironment by providing the enzyme its activity from the buffering solution., 34 The reduction of immobilized laccase activity might also be caused by enzyme leakage from the support material, as well as the microbial degradation and the change of surrounding microenvironments. ${ }^{20,45,46}$ Hence, the enzyme immobilized in $\mathrm{Fe}_{3} \mathrm{O}_{4}-\mathrm{MWCNT} @ \mathrm{SiO}_{2}$ can be broadly utilized for diverse environment and industrial applications.

Kinetic Analysis of the Free and Immobilized Laccase. The kinetic analysis of the free and immobilized laccase including the maximum velocity $\left(V_{\max }\right)$ and Michaelis constant $\left(K_{\mathrm{m}}\right)$ was performed using diverse concentrations of 2,2'azino-bis(3-ethylbenzothiazoline-6-sulfonic acid) (ABTS) as a substrate and was represented in Table 1 , and the results were

Table 1. Enzyme Kinetics Constant of the Free Laccase and Immobilized Laccase

\begin{tabular}{lcc}
\multicolumn{1}{c}{ enzymes } & $K_{\mathrm{m}}(\mathrm{mM})$ & $V_{\max }(\mathrm{mM} / \mathrm{min})$ \\
free laccase & 0.502 & 8.663 \\
immobilized laccase & 0.447 & 20.785
\end{tabular}

obtained from the Lineweaver-Burk plots. The immobilized and free laccase showed $V_{\max }$ values of 20.785 and $8.663 \mathrm{mM}$ / min, respectively. The $K_{\mathrm{m}}$ values for the immobilized and free laccase were 0.447 and $0.502 \mathrm{mM}$, respectively. The obtained results indicated that the laccase immobilized in $\mathrm{Fe}_{3} \mathrm{O}_{4}$ MWCNT@SiO 2 had a lower $K_{\mathrm{m}}$ compared to the free laccase, which showed the augmented affinity between the immobilized enzyme and the substrate. Similar results of lower $K_{\mathrm{m}}$ after immobilizing the enzyme have been published. ${ }^{37,53}$ The $V_{\max }$ value of the laccase immobilized in $\mathrm{Fe}_{3} \mathrm{O}_{4}$-MWCNT@SiO was higher compared to that of the free laccase. This indicates that the immobilization process may lead to a suitable structural change of laccase, which facilitates the substrate to be accessed easily on the active site of the enzyme, as well as the high surface area to volume ratio. Moreover, the strong interaction between the enzyme-substrate complex could increase the reaction rate to some degree. ${ }^{53}$
Decolorization of Azo Dyes Using the Free Enzyme, Immobilized Enzyme, and $\mathrm{Fe}_{3} \mathrm{O}_{4}-\mathrm{MWCNT@SiO}$. Dyes are commonly used in the textile industry or other sectors, and they create severe problems for marine life and the environment. The ability of the laccase enzyme to decolorize the dye depends considerably on the composition of the dye since the decolorization process varies accordingly.,20 Decolorization of Acid Red 88, Eriochrome Black T, and Reactive black 5 azo dyes was carried out utilizing $\mathrm{Fe}_{3} \mathrm{O}_{4}$ MWCNT@SiO ${ }_{2}$, free laccase, and laccase immobilized in $\mathrm{Fe}_{3} \mathrm{O}_{4}$-MWCNT@SiO . The decolorization of each azo dye was performed by using batch mode in a separate $100 \mathrm{~mL}$ oneneck round flask in which a certain quantity of $\mathrm{Fe}_{3} \mathrm{O}_{4}$ MWCNT@SiO 2 , free laccase, laccase immobilized in $\mathrm{Fe}_{3} \mathrm{O}_{4}$ MWCNT@SiO ${ }_{2}$, and dyes was applied in sequence.

The decolorization was performed under optimized conditions for $3.5 \mathrm{~h}$ without a mediator under continuous stirring. ${ }^{2,48}$ From the obtained results, the highest decolorization of Acid Red 88 (98\%), Eriochrome Black T (99\%), and Reactive Black 5 (66\%) was achieved in $3.5 \mathrm{~h}$ using the immobilized enzyme. However, with the free enzyme, the decolorization of Acid Red 88, Eriochrome Black T, and Reactive Black 5 was 95, 96, and 64\%, respectively, under the same conditions. In addition, the decolorization of these azo dyes was carried out using individual $\mathrm{Fe}_{3} \mathrm{O}_{4}-\mathrm{MWCNT@SiO}$; the decolorization of Acid Red 88, Eriochrome Black T, and Reactive Black 5 was 25,28 , and $24 \%$, respectively, under the same conditions, and the obtained results were represented in Figure 6.

The increased decolorization efficiencies of all azo dyes for the laccase immobilized in $\mathrm{Fe}_{3} \mathrm{O}_{4}-\mathrm{MWCNT} @ \mathrm{SiO}_{2}$ as opposed to the free form may be due to a close association between dyes and the laccase immobilized in $\mathrm{Fe}_{3} \mathrm{O}_{4}-\mathrm{MWCNT} @ \mathrm{SiO}_{2}$, a high mass transfer rate, and the fast access of laccase to the substrate. ${ }^{3,48,49}$ The results showed that the laccase enzyme is capable of decolorizing various coloring agents, and therefore, a higher percentage of decolorization was obtained using the immobilized enzyme than the free enzyme and $\mathrm{Fe}_{3} \mathrm{O}_{4}$ MWCNT@SiO ${ }_{2}$. Similar findings have been published by Othman et al. ${ }^{54}$ and Kunamneni et al., ${ }^{55}$ who used immobilized laccase for the decolorization of Reactive Black 5 dye, and Larissa et al. ${ }^{34}$ reported the decolorization of Acid Red 88 by immobilized laccase with thiosulfinate-agarose as a carrier. However, the time used was higher compared to the decolorization using laccase@ $\mathrm{Fe}_{3} \mathrm{O}_{4}-\mathrm{MWCNT} @ \mathrm{SiO}_{2}$ employed in the present study. The reduction in the time used for decolorization employing laccase@ $\mathrm{Fe}_{3} \mathrm{O}_{4}-\mathrm{MWCNT} @ \mathrm{SiO}_{2}$ could account for the quick mass and high surface area to volume ratio of the laccase@ $\mathrm{Fe}_{3} \mathrm{O}_{4}-\mathrm{MWCNT} @ \mathrm{SiO}_{2}$ and the high affinity of laccase to the substrate, which proves the strong interaction of the enzyme molecules with the substrate. ${ }^{53,44}$

However, the lower decolorization of Reactive Black 5 was observed due to the high redox potential of Reactive Black 5 with steric obstruction, which could limit the adsorption of these groups $\left(-\mathrm{NH}_{2}\right.$ and $\left.-\mathrm{OH}\right)$ to laccase molecules. ${ }^{54,55}$ Table 2 summarizes the process of decolorization of dyes previously mentioned. As can be seen from Table 2, the proposed study showed a high decolorization efficiency in a shorter time without mediators relative to previously described methods, which showed an improved affinity between the immobilized enzyme and the substrate, ${ }^{53}$ making the laccase immobilized in $\mathrm{Fe}_{3} \mathrm{O}_{4}$-MWCNT@SiO 2 more flexible for environmental and industrial applications. 

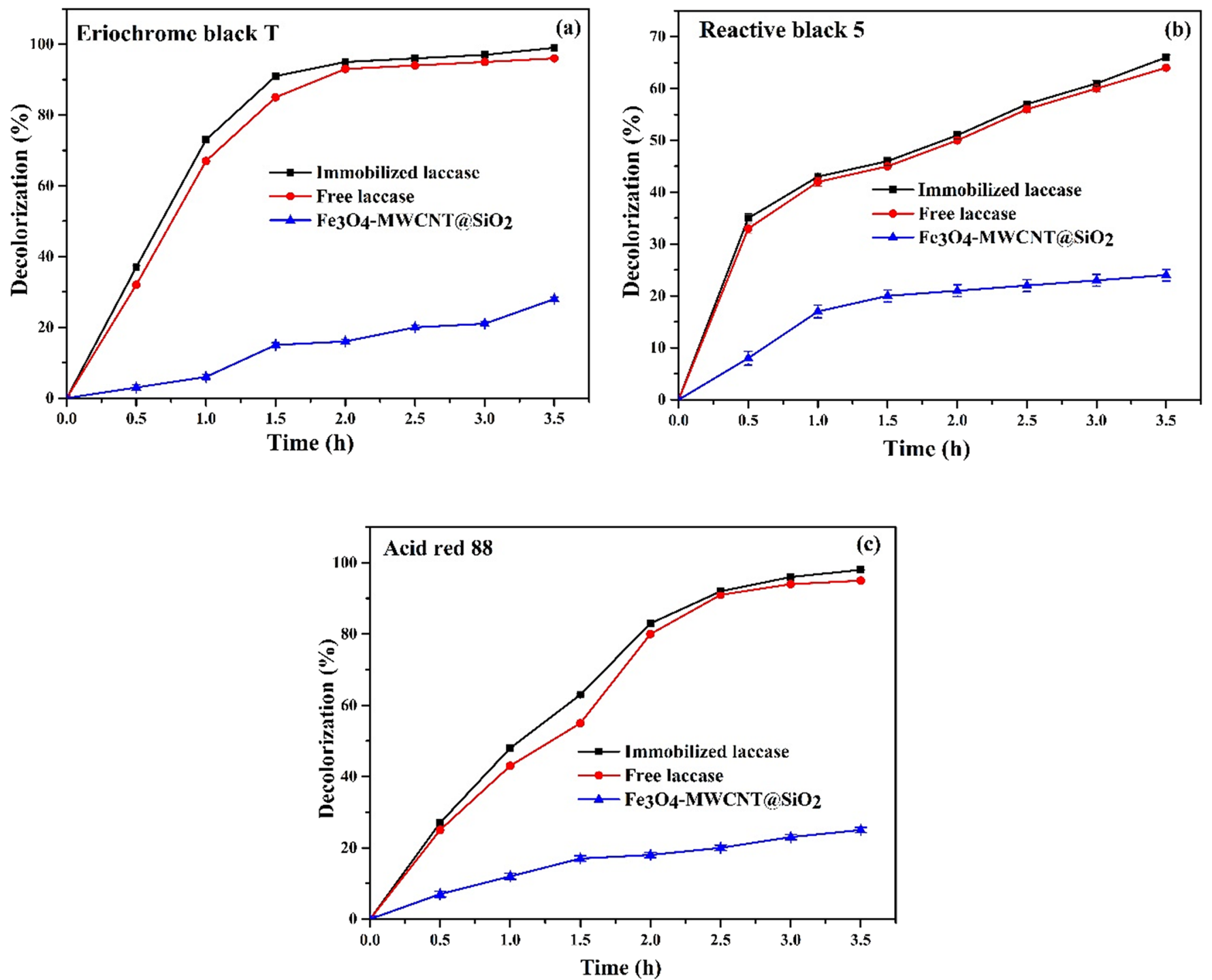

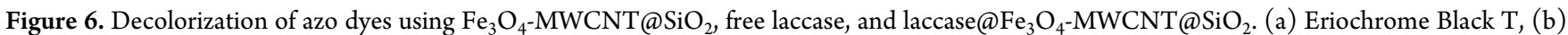
Reactive Black 5, and (c) Acid Red 88. Dyes were prepared in a $0.2 \mathrm{mM}$ phosphate buffer ( $\mathrm{pH} \mathrm{3.0)}$ ), and the decolorization of dyes was performed without a redox mediator at $60{ }^{\circ} \mathrm{C}$ under different time intervals.

Table 2. Comparison of the Decolorization Efficiency of the Presented Method with the Reported Works

\begin{tabular}{|c|c|c|c|c|c|c|}
\hline support material & enzyme & $\begin{array}{l}\text { immobilization } \\
\text { method }\end{array}$ & pollutants & $\begin{array}{l}\text { reaction } \\
\text { conditions }\end{array}$ & $\begin{array}{l}\text { decolorization } \\
\text { efficiency (\%) }\end{array}$ & references \\
\hline multiwalled carbon nanotubes & $\begin{array}{l}\text { laccase from } \\
\text { Myceliophthora } \\
\text { thermophile }\end{array}$ & $\begin{array}{l}\text { covalent } \\
\text { immobilization }\end{array}$ & Reactive Black 5 & $\begin{array}{l}\mathrm{pH} 5,25 \\
{ }^{\circ} \mathrm{C}, 24 \mathrm{~h}\end{array}$ & 84 & 54 \\
\hline $\mathrm{TiO}_{2}-\mathrm{ZrO}_{2}-\mathrm{SiO}_{2}$ & $\begin{array}{l}\text { laccase from Trametes } \\
\text { versicolor }\end{array}$ & $\begin{array}{l}\text { adsorption } \\
\text { immobilization }\end{array}$ & Reactive Black 5 & $\begin{array}{l}\mathrm{pH} 5,25 \\
{ }^{\circ} \mathrm{C}, 24 \mathrm{~h}\end{array}$ & 77 & 35 \\
\hline thiosulfinate-agarose & $\begin{array}{l}\text { laccase from Trametes } \\
\text { villose }\end{array}$ & $\begin{array}{l}\text { covalent } \\
\text { immobilization }\end{array}$ & Acid Red 88 & $22^{\circ} \mathrm{C}, 24 \mathrm{~h}$ & 97 & 34 \\
\hline carbon nanotubes & $\begin{array}{l}\text { lignin peroxidase from } \\
\text { Ganoderma lucidum }\end{array}$ & $\begin{array}{l}\text { covalent } \\
\text { immobilization }\end{array}$ & Remazol Brilliant Blue R & $\begin{array}{l}\mathrm{pH} 3.5,25 \\
{ }^{\circ} \mathrm{C}, 24 \mathrm{~h}\end{array}$ & 78 & 56 \\
\hline $\begin{array}{l}\text { poly }(4 \text {-vinyl pyridine }) / \mathrm{Cu}(\mathrm{II}) \\
\text { magnetic beads }\end{array}$ & $\begin{array}{l}\text { laccase from Trametes } \\
\text { versicolor }\end{array}$ & $\begin{array}{l}\text { adsorption } \\
\text { immobilization }\end{array}$ & $\begin{array}{l}\text { Reactive Green 19, Reactive Red 2, } \\
\text { Reactive Brown } 10\end{array}$ & $\begin{array}{c}\mathrm{pH} 5.5,30 \\
{ }^{\circ} \mathrm{C}, 18 \mathrm{~h}\end{array}$ & $64,88,91$ & 57 \\
\hline $\begin{array}{l}\text { mesoporous carbon from pecan } \\
\text { shells }\end{array}$ & $\begin{array}{l}\text { laccase from Trametes } \\
\text { versicolor }\end{array}$ & $\begin{array}{l}\text { adsorption } \\
\text { immobilization }\end{array}$ & $\begin{array}{c}\text { Reactive Black 5, Reactive Red 2, } \\
\text { Acid Blue 74, Acid Orange } 7\end{array}$ & $\begin{array}{l}\mathrm{pH} 6,30 \\
{ }^{\circ} \mathrm{C}, 72 \mathrm{~h}\end{array}$ & $5,48,92,94$ & 58 \\
\hline $\mathrm{Fe}_{3} \mathrm{O}_{4}-\mathrm{MWCNT} @ \mathrm{SiO}_{2}$ & $\begin{array}{l}\text { laccase from Trametes } \\
\text { versicolor }\end{array}$ & $\begin{array}{l}\text { covalent } \\
\text { immobilization }\end{array}$ & $\begin{array}{l}\text { Acid Red 88, Eriochrome Black T, } \\
\text { Reactive Black } 5\end{array}$ & $\begin{array}{l}\mathrm{pH} 3,60 \\
{ }^{\circ} \mathrm{C}, 3.5 \mathrm{~h}\end{array}$ & $98,99,66$ & this work \\
\hline $\begin{array}{l}\mathrm{TiO}_{2} \text { sol-gel-coated PAN/O- } \\
\text { MMT composite nanofibers }\end{array}$ & laccase & adsorption & Crystal Violet & $6 \mathrm{~h}$ & 95 & 62 \\
\hline
\end{tabular}

Conclusions. In summary, novel mesoporous silica coated magnetic multiwalled carbon nanotubes $\left(\mathrm{Fe}_{3} \mathrm{O}_{4}\right.$-MWCNT@
$\mathrm{SiO}_{2}$ ) were successfully prepared, and their structural morphology was investigated. Laccase enzyme was successfully 
immobilized by glutaraldehyde as a cross-linker in the assynthesized $\mathrm{Fe}_{3} \mathrm{O}_{4}-\mathrm{MWCNT} @ \mathrm{SiO}_{2}$. The pH and temperature optimum values for the immobilized laccase were $\mathrm{pH} 3$ and 60 ${ }^{\circ} \mathrm{C}$, respectively. In contrast to the free laccase, the immobilized laccase showed a wide $\mathrm{pH}$ range, enhanced $\mathrm{pH}$ and thermal stability, as well as storage stability. The biocatalysts could be reused for up to 10 repeatable cycles and easily separated from the reaction solution using a magnet. In addition, the biocatalysts exhibited a lower $K_{\mathrm{m}}(0.447 \mathrm{mM})$ and a higher $V_{\max }(20.785 \mathrm{mM} / \mathrm{min})$ than the free laccase, indicating a high affinity of the immobilized enzyme to the substrate. In addition, the biocatalysts have been tested for the decolorization of azo dyes and have been shown to be extremely competitive compared to the free enzyme. Based on these results, the potential use of the laccase immobilized in $\mathrm{Fe}_{3} \mathrm{O}_{4}-\mathrm{MWCNT} @ \mathrm{SiO}_{2}$ for dye wastewater treatment was recommended for a promising future use in industrial applications. However, the present method still has some problems, such as enzyme loss during the reusability or washing processes. Further study is still needed to apply this method for immobilizing other types of enzymes and extend this approach to other forms of dyes as well as to industrial effluents.

\section{EXPERIMENTAL DETAILS}

Materials are reported in the Supporting Information.

Synthesis of Acid-Activated MWCNTs. To synthesize the functionalized multiwalled carbon nanotubes (MWCNTs), the reported method with some modification was utilized. ${ }^{22,36}$ Briefly, $0.5 \mathrm{~g}$ of MWCNTs was suspended in $100 \mathrm{~mL}$ of a solution containing $\mathrm{H}_{2} \mathrm{SO}_{4} / \mathrm{HNO}_{3}$ mixture $(3: 1 \mathrm{v} / \mathrm{v})$ and then ultrasonicated for $3 \mathrm{~h}$ at $40{ }^{\circ} \mathrm{C}$. After that, the mixture was centrifuged at $8000 \mathrm{rpm}$ for $10 \mathrm{~min}$ and washed thoroughly with distilled water several times. Finally, the acid-activated MWCNTs (MWCNT-COOH) were collected and dried in a vacuum oven at $60{ }^{\circ} \mathrm{C}$.

Synthesis of Magnetic MWCNTs. The magnetic multiwalled carbon nanotubes $\left(\mathrm{Fe}_{3} \mathrm{O}_{4}\right.$-MWCNTs $)$ were synthesized according to the reported procedure with some modification. ${ }^{59}$ Briefly, $40 \mathrm{~mL}$ of an ethylene glycol solution was added into the mixture of $700 \mathrm{mg} \mathrm{FeCl} \cdot 6 \mathrm{H}_{2} \mathrm{O}$ and $300 \mathrm{mg}$ of acid-treated MWCNTs. Subsequently, $1.8 \mathrm{~g}$ of sodium acetate was added and mixed under the ultrasonic condition at $25{ }^{\circ} \mathrm{C}$ until the solution became homogeneous. Finally, the mixed solution was transferred into the reaction pressure vessel and heated at 200 ${ }^{\circ} \mathrm{C}$ for $16 \mathrm{~h}$. The obtained product was cooled down; washed with water and ethanol three times, respectively; and finally then dried at $60{ }^{\circ} \mathrm{C}$ overnight to obtain the final product.

Preparation of $\mathrm{Fe}_{3} \mathrm{O}_{4}-\mathrm{MWCNT} @ \mathrm{SiO}_{2}$ Nanocomposites. The process of coating mesoporous silica on the assynthesized magnetic multiwalled carbon nanotubes $\left(\mathrm{Fe}_{3} \mathrm{O}_{4}\right.$ MWCNT) was performed via a solution-phase approach using cetyltrimethyl ammonium bromide (CTAB) as a surfactant. $^{36,60}$ Briefly, $0.5 \mathrm{~g}$ of magnetic multiwalled carbon nanotubes $\left(\mathrm{Fe}_{3} \mathrm{O}_{4}\right.$-MWCNTs), $1 \mathrm{~g}$ of $\mathrm{CTAB}, 40 \mathrm{~mL}$ of ethanol, $1 \mathrm{~mL}$ of ammonium hydroxide $\left(\mathrm{NH}_{4} \mathrm{NO}_{3}\right)$, and deionized water $(1 \mathrm{~mL})$ were added in series into a threenecked flask followed by ultrasonic distribution for $0.5 \mathrm{~h}$ to form a homogeneous mixture. With vigorous stirring, $2 \mathrm{~mL}$ of tetraethylorthosilicate (TEOS) was added slowly into the $\mathrm{Fe}_{3} \mathrm{O}_{4}$-MWCNTs solution and maintained at $40{ }^{\circ} \mathrm{C}$ for $12 \mathrm{~h}$ with a stirring speed of $300 \mathrm{rpm}$. Then, the mixture was magnetically separated and washed with distilled water three times, and the obtained $\mathrm{Fe}_{3} \mathrm{O}_{4}-\mathrm{MWCNTs} @ \mathrm{SiO}_{2}$ nanoparticles were dried at $60{ }^{\circ} \mathrm{C}$. Moreover, a facile and efficient ionexchange method was utilized to obtain the mesoporous silica coated $\mathrm{Fe}_{3} \mathrm{O}_{4}$-MWCNT. Briefly, 0.5 g of $\mathrm{Fe}_{3} \mathrm{O}_{4}$-MWCNTs@ $\mathrm{SiO}_{2}$ was added in $90 \mathrm{~mL}$ of ethanol comprising $1.8 \mathrm{~g}$ of ammonium nitrate, and the mixture was magnetically stirred at $60{ }^{\circ} \mathrm{C}$ for $30 \mathrm{~min}$, washed with cold ethanol, and finally dried at $60{ }^{\circ} \mathrm{C}$.

Characterization of $\mathrm{Fe}_{3} \mathrm{O}_{4}-\mathrm{MWCNTs}$ and $\mathrm{Fe}_{3} \mathrm{O}_{4}$ MWCNTs@SiO . To get the morphological description of the pristine multiwalled carbon nanotubes (MWCNTs), magnetic multiwalled carbon nanotubes $\left(\mathrm{Fe}_{3} \mathrm{O}_{4}\right.$-MWCNTs), and mesoporous silica coated magnetic multiwalled carbon nanotubes $\left(\mathrm{Fe}_{3} \mathrm{O}_{4}-\mathrm{MWCNTs} @ \mathrm{SiO}_{2}\right)$, the scanning electron microscopy (SEM) images were recorded using a Nova Nano SEM 450 field emission microscope with an energy-dispersive X-ray spectra (EDX) detector. The compositions of $\mathrm{Fe}_{3} \mathrm{O}_{4}$ MWCNTs and $\mathrm{Fe}_{3} \mathrm{O}_{4}-\mathrm{MWCNTs} @ \mathrm{SiO}_{2}$ were examined by Fourier transform infrared spectroscopy (FTIR) (Bruker Vector 22). The nitrogen adsorption-desorption isotherms were recorded at $273.0 \mathrm{~K}$ with the Quantachrome Instruments version 11.04. The Brunauer-Emmett-Teller (BET) method was utilized to calculate the specific surface of the samples. The pore volumes and size distribution of the samples were calculated using the Barrett-Joyner-Halenda (BJH) model.

Preparation of the Immobilized Enzyme. Before immobilizing the enzyme, the support was first activated using glutaraldehyde as a cross-linker to add active aldehyde groups for linking laccase to the support. Briefly, $20 \mathrm{mg}$ of mesoporous silica coated magnetic multiwalled carbon nanotubes (MWCNT- $\mathrm{Fe}_{3} \mathrm{O}_{4} @ \mathrm{SiO}_{2}$ ) nanocomposites was added into $2 \mathrm{~mL}$ of a $1.5 \mathrm{wt} \%$ glutaraldehyde solution prepared in a buffer solution (PBS, $0.2 \mathrm{M}, \mathrm{pH} 8.0$ ). The resulting solution was shaken at a speed of $170 \mathrm{rpm}$ for $2 \mathrm{~h}$ at room temperature to activate $\mathrm{Fe}_{3} \mathrm{O}_{4}-\mathrm{MWCNTs} @ \mathrm{SiO}_{2}$. After the reaction, the suspension was magnetically separated. The solid particles (glutaraldehyde-activated $\mathrm{Fe}_{3} \mathrm{O}_{4}-\mathrm{MWCNTs} @ \mathrm{SiO}_{2}$ ) were washed with the same buffer to remove the unbound glutaraldehyde and dried overnight at $60{ }^{\circ} \mathrm{C}$.

Afterward, the laccase enzyme was immobilized on activated $\mathrm{Fe}_{3} \mathrm{O}_{4}$-MWCNTs@SiO 2 via the glutaraldehyde molecule. A fresh $10 \mathrm{mg} / \mathrm{mL}$ mixture of activated $\mathrm{Fe}_{3} \mathrm{O}_{4}-\mathrm{MWCNTs} @ \mathrm{SiO}_{2}$ was prepared by adding $20 \mathrm{mg}$ of activated $\mathrm{Fe}_{3} \mathrm{O}_{4}-\mathrm{MWCNTs} @$ $\mathrm{SiO}_{2}$ into $2 \mathrm{~mL}$ of a sodium acetate buffer $(0.2 \mathrm{~mol} / \mathrm{L}, \mathrm{pH} 4.0)$ solution comprising $12 \mathrm{mg} / \mathrm{mL}$ of laccase $(75 \mathrm{U} / \mathrm{mL})$. The resulting mixture of the support and laccase solution was then incubated at $25{ }^{\circ} \mathrm{C}$ with a shaking speed of $170 \mathrm{rpm}$ for $2 \mathrm{~h}$ to reach the equilibrium state. Then, the obtained immobilized laccase was magnetically separated, washed with a $0.2 \mathrm{M}$ sodium acetate buffer $(\mathrm{pH} 4.0)$, freeze-dried overnight, and stored at $4{ }^{\circ} \mathrm{C}$ for further use.

Enzymatic Activity Assay. Under assay conditions, $1 \mathrm{U}$ of enzyme activity corresponds to the enzyme quantity that transforms $1 \mu \mathrm{mol}$ of 2,2'-azino-bis(3-ethylbenzothiazoline-6sulfonic acid) (ABTS) per minute. ${ }^{44,61}$ The quantification of enzyme activity was measured after incubating $1.8 \mathrm{~mL}$ of the 3 $\mathrm{mM}$ ABTS solution prepared in a $0.2 \mathrm{M}$ acetate buffer solution (ABS, pH 4) with $0.2 \mathrm{~mL}$ of the free enzyme mixture at $25^{\circ} \mathrm{C}$ for about $5 \mathrm{~min}$, directly at $420 \mathrm{~nm}$; the absorbance was examined spectrophotometrically at $420 \mathrm{~nm}$.

At $25{ }^{\circ} \mathrm{C}, 20 \mathrm{mg}$ of the biocatalytic system (laccase@ $@ \mathrm{Fe}_{3} \mathrm{O}_{4}$ MWCNTs@SiO $\left.{ }_{2}\right), 1.3 \mathrm{~mL}$ of a sodium acetate buffer $(0.2 \mathrm{M}$, $\mathrm{pH} 4)$, and $0.7 \mathrm{~mL}$ of ABTS ( $3 \mathrm{mM}$ ) were mixed and then 
incubated for 5 min using a magnetic stirrer. Then, samples were filtered and the absorbance was spectrophotometrically tested at $420 \mathrm{~nm}$, and $36.0 \mathrm{mM}^{-1} \mathrm{~cm}^{-1}$ as the molar extinction coefficient of ABTS was used for determining the activities of enzymes. Finally, $\mathrm{U} / \mathrm{mL}$ as a unit for the free laccase activity was utilized, while $\mathrm{U} / \mathrm{mg}$ corresponded to the immobilized laccase. Relative activities were stated as the percentage of the initial activity fixed as $100 \%$. All experiments were performed three times separately. The influence of the glutaraldehyde concentration, activation time, enzyme concentrations, and immobilization time on the activities of laccase $@ \mathrm{Fe}_{3} \mathrm{O}_{4}$ MWCNTs@SiO 2 was also optimized.

The enzymatic kinetic parameters including $K_{\mathrm{m}}$ and $V_{\max }$ for the free laccase and laccase immobilized in $\mathrm{Fe}_{3} \mathrm{O}_{4}$-MWCNT@ $\mathrm{SiO}_{2}$ were tested by examining the hydrolytic activity of the laccase using a diverse concentration of the ABTS substrate $(0.1-2 \mathrm{mM})$ prepared in a buffer solution $(0.2 \mathrm{mM}, \mathrm{pH} 3.0)$ at $60{ }^{\circ} \mathrm{C}$. $V_{\max }$ and $K_{\mathrm{m}}$ were determined via Lineweaver-Burk plots. The following formula was utilized for activity calculation:

$$
\text { Activity }=\frac{A V / t \varepsilon}{m} \times 1000
$$

where $A$ is the absorbance change at $420 \mathrm{~nm}, V$ is the reaction volume, $t$ is the reaction time, $\varepsilon$ is the molar extinction coefficient for the ABTS oxidation, and $m$ is the amount of the nanobiocatalyst introduced into the reaction volume (in $\mathrm{mg}$ or $\mathrm{mL})$.

Biochemical Characterization of the Immobilized and Free Laccase. The effects of $\mathrm{pH}$ values on laccase activity were examined. Both the free laccase and laccase@ $@ \mathrm{Fe}_{3} \mathrm{O}_{4}$ MWCNT@SiO ${ }_{2}$ were incubated separately for $10 \mathrm{~min}$ for each reaction in different buffers with pHs ranging from 2.0 to 8.0 at $25{ }^{\circ} \mathrm{C}$ and $3 \mathrm{mM} \mathrm{2,2}$-azino-bis(3-ethylbenzothiazoline-6sulfonic acid) (ABTS) as the substrate. The stability of laccase against $\mathrm{pHs}$ was also examined. Both the free laccase and

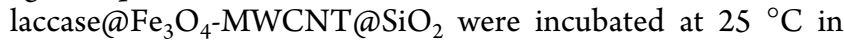
diverse buffers, a $0.2 \mathrm{M}$ sodium acetate buffer $(\mathrm{pH} 4.0)$ and a $0.2 \mathrm{M}$ phosphate buffer ( $\mathrm{pH} 8.0$ ), for $2.5 \mathrm{~h}$. Then, the residual activities were also examined.

The effect of temperature on enzyme activities was also investigated. Both the free laccase and laccase@ $\mathrm{Fe}_{3} \mathrm{O}_{4}$ MWCNT@SiO $\mathrm{Si}_{2}$ were incubated for $10 \mathrm{~min}$ at temperatures ranging from 30 to $80{ }^{\circ} \mathrm{C}$ using a buffer with $\mathrm{pH} 3$ and $3 \mathrm{mM}$ $\mathrm{ABTS}$ as the substrate; then, the residual activities were examined at $25{ }^{\circ} \mathrm{C}$ after cooling. At 60 and $70{ }^{\circ} \mathrm{C}$, the thermal stability against laccase activities was also tested. Both the free laccase and laccase@ $@ \mathrm{Fe}_{3} \mathrm{O}_{4}-\mathrm{MWCNT} @ \mathrm{SiO}_{2}$ were incubated at temperatures 60 and $70{ }^{\circ} \mathrm{C}$ using a buffer with $\mathrm{pH} 3.0$ for $3 \mathrm{~h}$. Finally, the residual activities were examined at $25{ }^{\circ} \mathrm{C}$. Aliquots of samples of $2 \mathrm{~mL}$ were taken at each time interval, filtrated, and then used for the laccase activity measurement. The experiments were repeated three times. The activity of laccase at the optimum temperature or $\mathrm{pH}$ was fixed as $100 \%$.

Reusability Assessment of the Immobilized Laccase. The main objective of immobilizing an enzyme is to make it more applicable for repeatable use, which is the main point for industrial and environmental applications. To examine this, the laccase@ $\mathrm{Fe}_{3} \mathrm{O}_{4}-\mathrm{MWCNT} @ \mathrm{SiO}_{2}$ were employed in the reac-

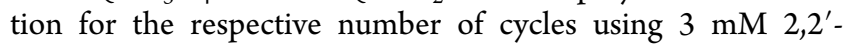
azino-bis(3-ethylbenzothiazoline-6-sulfonic acid) ABTS as a substrate and a $0.2 \mathrm{mM}$ sodium acetate buffer $(\mathrm{pH} \mathrm{3.0)}$ ) at 60 ${ }^{\circ} \mathrm{C}$. The enzyme activity of the immobilized laccase was tested at $25{ }^{\circ} \mathrm{C}$. After each enzyme activity measurement, the immobilized laccase was separated magnetically and washed several times with a $0.2 \mathrm{mM}$ sodium acetate buffer $(\mathrm{pH} 3.0)$ before being introduced into the next reaction.

Storage Stability of the Immobilized and Free Laccase. The storage of enzymes is a very important factor to consider for industrial applications. To study the stability of the enzyme in storage, laccase@ $\mathrm{Fe}_{3} \mathrm{O}_{4}-\mathrm{MWCNT} @ \mathrm{SiO}_{2}$ and free laccase were stored in a $0.2 \mathrm{mM}$ sodium acetate buffer with a $\mathrm{pH}$ of 3.0 at $4{ }^{\circ} \mathrm{C}$ for 30 days. Sampling was done at 5 day intervals, and the activity of laccase at the optimum temperature and $\mathrm{pH}$ on day zero was fixed as $100 \%$.

Decolorization Analysis. Acid Red 88, Eriochrome Black $\mathrm{T}$, and Reactive Black 5 were chosen as model dyes to test the decolorization capacity of the free laccase, $\mathrm{Fe}_{3} \mathrm{O}_{4}$-MWCNT@ $\mathrm{SiO}_{2}$, and laccase@ $\mathrm{Fe}_{3} \mathrm{O}_{4}-\mathrm{MWCNT} @ \mathrm{SiO}_{2}$. In this study, the decolorization was performed without a mediator; a stock solution of the dyes at a concentration of $40 \mathrm{mg} / \mathrm{L}$ in the buffer $(0.2 \mathrm{M}, \mathrm{pH} 3.0)$ was prepared. The prepared solution was kept in the dark and employed in the experiments. The reaction process was accomplished at $60{ }^{\circ} \mathrm{C}$ with stirring for $3.5 \mathrm{~h}$. Briefly, $30 \mathrm{mg}$ of the biocatalytic system $(1.222 \mathrm{U}), 2 \mathrm{~mL}$ from $12 \mathrm{mg} / \mathrm{mL}$ for the free enzyme $(75 \mathrm{U} / \mathrm{mL})$, or $30 \mathrm{mg}$ of $\mathrm{Fe}_{3} \mathrm{O}_{4}$-MWCNT@SiO 2 and $30 \mathrm{~mL}$ of dyes were mixed in a $100 \mathrm{~mL}$ one-neck round flask separately for each dye. After that, $1.5 \mathrm{~mL}$ was taken at particular time intervals and filtered, and subsequently, the absorbance was examined spectrophotometrically through different wavelengths of the utilized dyes such as Eriochrome Black T(523 nm), Acid Red 88 (505 nm), and Reactive Black $5(597 \mathrm{~nm})$. The percentage of decolorization was calculated as follows:

$$
D=\frac{B-C}{B} \times 100
$$

where $D$ is the decolorization percentage, $B$ is the initial absorbance, and $C$ is the final absorbance of the dye at each time interval.

\section{ASSOCIATED CONTENT}

\section{Supporting Information}

The Supporting Information is available free of charge at https://pubs.acs.org/doi/10.1021/acsomega.0c05081.

Materials, scanning electron microscopy (SEM) images (Figure S1), energy-dispersive X-ray spectra (EDX) (Figure S2), the photograph of magnetic separation (Figure S3), and optimization of immobilization conditions (PDF)

\section{AUTHOR INFORMATION}

\section{Corresponding Authors}

Li Ma - School of Chemical Engineering and Technology, Hebei University of Technology, Tianjin 300130, China; Email: mali0502@hebut.edu.cn

Yanjun Jiang - School of Chemical Engineering and Technology, Hebei University of Technology, Tianjin 300130, China; (1) orcid.org/0000-0003-1470-2102;

Email: yanjunjiang@hebut.edu.cn

\section{Authors}

Pascal Habimana - School of Chemical Engineering and Technology, Hebei University of Technology, Tianjin 300130, China 
Jing Gao - School of Chemical Engineering and Technology, Hebei University of Technology, Tianjin 300130, China

Jean Pierre Mwizerwa - College of Mechatronics and Control Engineering, Shenzhen University, Shenzen 518060, China

Jean Bernard Ndayambaje - University of Rwanda, College of Science and Technology, 3900 Kigali, Rwanda

Hengrao Liu - School of Chemical Engineering and Technology, Hebei University of Technology, Tianjin 300130, China

Pengqian Luan - School of Chemical Engineering and Technology, Hebei University of Technology, Tianjin 300130, China

Complete contact information is available at:

https://pubs.acs.org/10.1021/acsomega.0c05081

\section{Author Contributions}

The manuscript was written through the contributions of all authors. All authors have approved the final version of the manuscript.

\section{Notes}

The authors declare no competing financial interest.

\section{ACKNOWLEDGMENTS}

This work was supported by the National Nature Science Foundation of China $(21576068,21276060,21276062$, and 21306039), the Natural Science Foundation of Tianjin (16JCY-BJC19800), the Natural Science Foundation of Hebei Province (B2015202082, B2016202027, and B2017202056), the Program for Top 100 Innovative Talents in Colleges and Universities of Hebei Province (SLRC2017029), and Hebei High-level personnel of support program (A2016002027).

\section{REFERENCES}

(1) Benkhaya, S.; M'Rabet, S.; El Harfi, A. Classifications, properties, recent synthesis and applications of azo dyes. Heliyon. 2020, 6, e03271.

(2) Ladole, M. R.; Pokale, P. B.; Patil, S. S.; Belokar, P. G.; Pandit, A. B. Laccase immobilized peroxidase mimicking magnetic metal organic Frameworks for industrial dye degradation. Bioresour. Technol. 2020, 317, 124035.

(3) Zofair, S. F. F.; Arsalan, A.; Khan, M. A.; Alhumaydhi, F. A.; Younus, H. Immobilization of laccase on sepharose-linked antibody support for decolourization of phenol red. Int. J. Biol. Macromol. 2020, $161,78-87$.

(4) Li, Z.; Chen, Z.; Zhu, Q.; Song, J.; Li, S.; Liu, X. Improved performance of immobilized laccase on $\mathrm{Fe}_{3} \mathrm{O}_{4} @ \mathrm{C}-\mathrm{Cu}^{2+}$ nanoparticles and its application for biodegradation of dyes. J. Hazard. Mater. 2020, 399, 123088.

(5) Yusof, N. H.; Foo, K. Y.; Hameed, B. H.; Hussin, M. H.; Lee, H. K.; Sabar, S. One-step synthesis of chitosan-polyethyleneimine with calcium chloride as effective adsorbent for Acid Red 88 removal. Int. J. Biol. Macromol. 2020, 157, 648-658.

(6) Yu, S.; Wang, J.; Cui, J. Preparation of a novel chitosan-based magnetic adsorbent Cts@SnO $\mathrm{SnFe}_{2} \mathrm{O}_{4}$ for effective treatment of dye wastewater. Int. J. Biol. Macromol. 2020, 156, 1474-1482.

(7) Weldegebrieal, G. K. Synthesis method, antibacterial and photocatalytic activity of $\mathrm{ZnO}$ nanoparticles for azo dyes in wastewater treatment: A Review. Inorg. Chem. Commun. 2020, 120, 108140.

(8) Zhao, B.; Zhu, Z.; Qin, X. D.; Li, Z.; Zhang, H. Highly efficient and stable CuZr-based metallic glassy catalysts for azo dye degradation. J. Mater. Sci. Technol. 2020, 46, 88-97.

(9) Franca, R. D. G.; Vieira, A.; Carvalho, G.; Oehmen, A.; Pinheiro, H. M.; Barreto Crespo, M. T.; Lourenco, N. D. Oerskovia paurometabola can efficiently decolorize azo dye Acid Red 14 and remove its recalcitrant metabolite. Ecotoxicol. Environ. Saf. 2020, 191, 110007.

(10) Kassem Hami, H.; Fahmi Abbas, R.; Amer Waheb, A.; Ibrahim Mahdi, N. Removal of Eriochrom Black $\mathrm{T}$ from aqueous solution using $\mathrm{Al} 2 \mathrm{O} 3$ surface: Linear and non-linear isotherm models, error analysis and thermodynamic studies. Mater. Today 2020, 20, 599604.

(11) Qiu, X.; Wang, Y.; Xue, Y.; Li, W.; Hu, Y. Laccase immobilized on magnetic nanoparticles modified by amino-functionalized ionic liquid via dialdehyde starch for phenolic compounds biodegradation. Chem. Eng. J. 2020, 391, 123564.

(12) Goud, B. S.; Cha, H. L.; Koyyada, G.; Kim, J. H. Augmented biodegradation of textile azo dye effluents by plant Endophytes: A sustainable, eco-friendly alternative. Curr. Microbiol. 2020, 77, 32403255.

(13) Taghizadeh, T.; Talebian-Kiakalaieh, A.; Jahandar, H.; Amin, M.; Tarighi, S.; Faramarzi, M. A. Biodegradation of bisphenol a by the immobilized laccase on some synthesized and modified forms of Zeolite Y. J. Hazard. Mater. 2020, 386, 121950.

(14) Shakerian, F.; Zhao, J.; Li, S. P. Recent development in the application of immobilized oxidative enzymes for bioremediation of hazardous micropollutants - a Review. Chemosphere 2020, 239, 124716.

(15) Darwesh, O. M.; Matter, I. A.; Eida, M. F. Development of peroxidase enzyme immobilized magnetic nanoparticles for bioremediation of textile wastewater dye. J. Environ. Chem. Eng. 2019, 7, 102805.

(16) Bayburt, C.; Karaduman, A. B.; Yenice Gürsu, B.; Tuncel, M.; Yamaç, M. Decolourization and detoxification of textile dyes by lentinus arcularius in immersion bioreactor scale. Int. J. Environ.Sci. Technol. 2020, 17, 945-958.

(17) Guo, J.; Liu, X.; Zhang, X.; Wu, J.; Chai, C.; Ma, D.; Chen, Q.; Xiang, D.; Ge, W. Immobilized lignin peroxidase on Fe3O4@SiO2@ Polydopamine nanoparticles for degradation of organic pollutants. Int. J. Biol. Macromol. 2019, 138, 433-440.

(18) Vikrant, K.; Giri, B. S.; Raza, N.; Roy, K.; Kim, K.-H.; Rai, B. N.; Singh, R. S. Recent advancements in bioremediation of dye: Current status and challenges. Bioresour. Technol. 2018, 253, 355367.

(19) Kiran, R. K. R.; Bhatia, R. K.; Rana, D. S.; Bhatt, A. K.; Thakur, $\mathrm{N}$. Fabrication of thermostable and reusable nanobiocatalyst for dye decolourization by immobilization of lignin peroxidase on Graphene Oxide functionalized $\mathrm{MnFe} 2 \mathrm{O} 4$ superparamagnetic nanoparticles. Bioresour. Technol. 2020, 317, 124020.

(20) Zdarta, J.; Meyer, A. S.; Jesionowski, T.; Pinelo, M. Developments in support materials for immobilization of oxidoreductases: A comprehensive Review. Adv. Colloid Interface Sci. 2018, $258,1-20$.

(21) Costa, J. B.; Lima, M. J.; Sampaio, M. J.; Neves, M. C.; Faria, J. L.; Morales-Torres, S.; Tavares, A. P. M.; Silva, C. G. Enhanced biocatalytic sustainability of laccase by immobilization on functionalized carbon nanotubes/polysulfone membranes. Chem. Eng. J. 2019, 355, 974-985.

(22) Ranjan, B.; Pillai, S.; Permaul, K.; Singh, S. Simultaneous removal of heavy metals and cyanate in a wastewater sample using immobilized cyanate hydratase on magnetic-multiwall carbon nanotubes. J. Hazard. Mater. 2019, 363, 73-80.

(23) Guo, W.; Umar, A.; Alsaiari, M. A.; Wang, L.; Pei, M. Ultrasensitive and selective label-free aptasensor for the detection of penicillin based on nanoporous $\mathrm{PtTi} / \mathrm{Graphene}$ Oxide-Fe3O4/ MWCNT-Fe3O4 nanocomposite. Microchem. J. 2020, 158, 105270.

(24) Deng, R.; Gao, X.; Hou, J.; Lin, D. Multi-Omics analyses reveal molecular mechanisms for the antagonistic toxicity of carbon nanotubes and ciprofloxacin to Escherichia Coli. Sci. Total Environ. 2020, 726, 138288

(25) Wang, L.; Shen, C.; Cao, Y. PVP modified Fe3O4@SiO2 nanoparticles as a new adsorbent for hydrophobic substances. J. Phys. Chem. Solids 2019, 133, 28-34. 
(26) Altowayti, W. A. H.; Allozy, H. G. A.; Shahir, S.; Goh, P. S.; Yunus, M. A. M. A novel nanocomposite of aminated silica nanotube (MWCNT/Si/NH2) and its potential on adsorption of nitrite. Environ. Sci. Pollut. Res. Int. 2019, 26, 28737-28748.

(27) Othman, A. M.; Wollenberger, U. Amperometric biosensor based on coupling aminated laccase to functionalized carbon nanotubes for phenolics detection. Int. J. Biol. Macromol. 2020, 153, $855-864$.

(28) Romero-Arcos, M.; Pérez-Robles, J. F.; Garnica-Romo, M. G.; Luna-Martinez, M. S.; Gonzalez-Reyna, M. A. Synthesis and functionalization of carbon nanotubes and nanospheres as a support for the immobilization of an enzyme extract from the mushroom Trametes Versicolor. J. Mater. Sci. 2019, 54, 11671-11681.

(29) Bandar, S.; Anbia, M.; Salehi, S. Comparison of $\mathrm{MnO} 2$ modified and unmodified magnetic $\mathrm{Fe} 3 \mathrm{O} 4$ nanoparticle adsorbents and their potential to remove Iron and Manganese from aqueous media. J. Alloys Compd. 2020, 851, 156822.

(30) Zeng, H.; Huo, W. S.; Wang, F.; Ma, T. M. Negative impact of adjacent coordination on direct electrochemistry and enzymatic catalysis of laccase immobilization onto multi-Wall carbon nanotubes functionalized by perylene derivative. Macromol. Res. 2019, 27, 963973.

(31) Moreno, A. D.; Ibarra, D.; Eugenio, M. E.; Tomás-Pejó, E. Laccases as versatile enzymes: From industrial uses to novel applications. J. Chem. Technol. Biotechnol. 2019, 95, 481-494.

(32) Zhang, J.; Ding, S.; Ge, Y.; Li, Z. Enhanced removal of crystal Violet in water using a facile-fabricated and environmental-friendly laccase immobilized composite membrane. Process Biochem. 2020, 98, $122-130$.

(33) Kołodziejczak-Radzimska, A.; Budna, A.; Ciesielczyk, F.; Moszyński, D.; Jesionowski, T. Laccase from Trametes Versicolor supported onto mesoporous Al2O3: Stability tests and evaluations of catalytic activity. Process Biochem. 2020, 95, 71-80.

(34) Gioia, L.; Ovsejevi, K.; Manta, C.; Míguez, D.; Menéndez, P. Biodegradation of Acid dyes by an immobilized laccase: An ecotoxicological approach. Environ. Sci. Water Res. Technol. 2018, 4, 2125-2135.

(35) Antecka, K.; Zdarta, J.; Siwińska-Stefańska, K.; Sztuk, G.; Jankowska, E.; Oleskowicz-Popiel, P.; Jesionowski, T. Synergistic degradation of dye wastewaters using binary or ternary oxide systems with immobilized laccase. Catalysts 2018, 8, 402.

(36) Mohammadi, A. A.; Dehghani, M. H.; Mesdaghinia, A.; Yaghmaian, K.; Es'haghi, Z. Adsorptive removal of endocrine disrupting compounds from aqueous solutions using magnetic multi-wall carbon nanotubes modified with chitosan biopolymer based on response surface methodology: Functionalization, kinetics, and isotherms studies. Int. J. Biol. Macromol. 2020, 155, 1019-1029.

(37) Kumar, A.; Park, G. D.; Patel, S. K. S.; Kondaveeti, S.; Otari, S.; Anwar, M. Z.; Kalia, V. C.; et al. $\mathrm{SiO} 2$ microparticles with carbon nanotube-derived mesopores as an efficient support for enzyme immobilization. Chem. Eng. J. 2019, 359, 1252-1264.

(38) Tong, Y.; Zhang, M.; Xia, P.; Wang, L.; Zheng, J.; Li, W.; Xu, J. Progammed synthesis of magnetic mesoporous silica coated carbon nanotubes for organic pollutant adsorption. J. Magn. Magn. Mater. 2016, 406, 35-41.

(39) Zhou, L.; Luo, X.; Li, J.; Ma, L.; He, Y.; Jiang, Y.; Yin, L.; Gao, L. Meso-molding three-dimensionally ordered macroporous Alumina: A new platform to immobilize enzymes with high performance. Biochem. Eng. J. 2019, 146, 60-68.

(40) Rouhani, S.; Azizi, S.; Kibechu, R. W.; Mamba, B. B.; Msagati, T. A. M. Laccase Immobilized Fe3o4-Graphene Oxide nanobiocatalyst improves stability and immobilization efficiency in the green preparation of sulfa drugs. Catalysts 2020, 10, 459.

(41) Ren, D.; Cheng, Y.; Huang, C.; Wang, Z.; Zhang, S.; Zhang, X.; Gong, X. Study on remediation-improvement of 2,4-Dichlorophenol contaminated soil by organic fertilizer immobilized laccase. Soil Sediment Contam. 2020, 1-15.

(42) Kadam, A. A.; Shinde, S. K.; Ghodake, G. S.; Saratale, G. D.; Saratale, R. G.; Sharma, B.; Hyun, S.; Sung, J. S. Chitosan-Grafted
Halloysite Nanotubes-Fe3o4 composite for laccase-immobilization and sulfamethoxazole-degradation. Polymer 2020, 12, 2221.

(43) Kashefi, S.; Borghei, S. M.; Mahmoodi, N. M. Covalently immobilized laccase onto Graphene Oxide nanosheets: preparation, characterization, and biodegradation of azo dyes in colored wastewater. J. Mol. Liq. 2019, 276, 153-162.

(44) Muthuvelu, K. S.; Rajarathinam, R.; Selvaraj, R. N.; Rajendren, V. B. A novel method for improving laccase activity by immobilization onto Copper Ferrite nanoparticles for lignin degradation. Int. J. Biol. Macromol. 2020, 152, 1098-1107.

(45) Zhou, W.; Zhang, W.; Cai, Y. Laccase immobilization for water purification: A comprehensive Review. Chem. Eng. J. 2020, 403, 126272.

(46) Daronch, N. A.; Kelbert, M.; Pereira, C. S.; de Araújo, P. H. H.; de Oliveira, D. Elucidating the choice for a precise matrix for laccase immobilization: A Review. Chem.Eng. J. 2020, 397, 125506.

(47) Jun, L. Y.; Mubarak, N. M.; Yon, L. S.; Bing, C. H.; Khalid, M.; Jagadish, P.; Abdullah, E. C. Immobilization of peroxidase on functionalized MWCNTs-Buckypaper/Polyvinyl Alcohol nanocomposite membrane. Sci. Rep. 2019, 9, 2215.

(48) Yuan, H.; Chen, L.; Cao, Z.; Hong, F. F. Enhanced decolourization efficiency of textile dye Reactive Blue 19 in a horizontal rotating reactor using strips of BNC-immobilized laccase: Optimization of conditions and comparison of decolourization efficiency. Biochem. Eng. J. 2020, 156, 107501.

(49) Tuncay, D.; Yagar, H. Decolorization of Reactive Blue-19 Textile Dye by Boletus Edulis laccase immobilized onto rice husks. Int. J.Environ. Sci. Technol. 2020, 17, 3177-3188.

(50) Wlizło, K.; Polak, J.; Kapral-Piotrowska, J.; Grąz, M.; Paduch, R.; Jarosz-Wilkołazka, A. Influence of carrier structure and physicochemical factors on immobilisation of fungal laccase in terms of Bisphenol a removal. Catalysts 2020, 10, 951.

(51) Tavares, A. P. M.; Silva, C. G.; Drazic, G.; Silva, A. M. T.; Loureiro, J. M.; Faria, J. L. Laccase immobilization over multi-Walled carbon nanotubes: Kinetic, thermodynamic and stability studies. $J$. Colloid Interface Sci. 2015, 454, 52-60.

(52) Liu, Y.; Zeng, Z.; Zeng, G.; Tang, L.; Pang, Y.; Li, Z.; Liu, C.; et al. Immobilization of laccase on magnetic bimodal mesoporous carbon and the application in the removal of Phenolic Compounds. Bioresour. Technol. 2012, 115, 21-26.

(53) Cao, G.; Gao, J.; Zhou, L.; Huang, Z.; He, Y.; Zhu, M.; Jiang, Y. Fabrication of $\mathrm{Ni2}+-$ nitrilotriacetic acid functionalized magnetic mesoporous silica nanoflowers for one pot purification and immobilization of His-tagged $\omega$-transaminase. Biochem. Eng. J. 2017, $128,116-125$.

(54) Othman, A. M.; González-Domínguez, E.; Sanromán, Á.; Correa-Duarte, M.; Moldes, D. Immobilization of laccase on functionalized multiwalled carbon nanotube membranes and application for dye decolorization. RSC Adv. 2016, 6, 114690114697.

(55) Kunamneni, A.; Ghazi, I.; Camarero, S.; Ballesteros, A.; Plou, F. J.; Alcalde, M. Decolorization of synthetic dyes by laccase immobilized on epoxy-activated carriers. Process Biochem. 2008, 43, $169-178$

(56) Oliveira, S. F.; da Luz, J. M. R.; Kasuya, M. C. M.; Ladeira, L. O.; Correa Junior, A. Enzymatic extract containing lignin peroxidase immobilized on carbon nanotubes: Potential biocatalyst in dye decolourization. Saudi J. Biol. Sci. 2018, 25, 651-659.

(57) Bayramoğlu, G.; Yilmaz, M.; Arica, M. Y. Reversible immobilization of laccase to Poly(4-Vinylpyridine) Grafted and $\mathrm{Cu}(\mathrm{II})$ chelated magnetic beads: Biodegradation of Reactive dyes. Bioresour. Technol. 2010, 101, 6615-6621.

(58) Ramírez-Montoya, L. A.; Hernández-Montoya, V.; MontesMorán, M. A.; Jáuregui-Rincón, J.; Cervantes, F. J. Decolorization of dyes with different molecular properties using free and immobilized laccases from Trametes Versicolor. J. Mol. Liq. 2015, 212, 30-37.

(59) Li, F.; Han, J.; Jiang, L.; Wang, Y.; Li, Y.; Dong, Y.; Wei, Q. An ultrasensitive Sandwich-type electrochemical immunosensor based on signal amplification strategy of gold nanoparticles functionalized 
magnetic multi-Walled carbon nanotubes loaded with Lead ions. Biosens. Bioelectron. 2015, 68, 626-632.

(60) Oke, J. A.; Idisi, D. O.; Sarma, S.; Moloi, S. J.; Ray, S. C.; Chen, K. H.; Ghosh, A.; Shelke, A.; Pong, W. F. Electronic, Electrical, and magnetic behavioral change of SiO2-Np-Decorated MWCNTs. ACS Omega 2019, 4, 14589-14598.

(61) Ulu, A.; Birhanli, E.; Boran, F.; Koytepe, S.; Yesilada, O.; Ates, B. Laccase-conjugated thiolated chitosan-Fe3O4 hybrid composite for biocatalytic degradation of organic dyes. Int. J. Biol. Macromol. 2020, $150,871-884$.

(62) Wang, Q.; Wang, T.; Lv, Z.; Cui, M.; Zhao, Z.; Cao, X.; Wei, Q. $\mathrm{TiO} 2$ Sol-Gel Coated Pan/O-MMT multi-functional composite nanofibrous membrane used as the support for laccase immobilization: Synergistic effect between the membrane support and enzyme for dye degradation. Polymer 2020, 12, 139. 